\title{
GTA Weld Brazing a Joint of Aluminum to Stainless Steel
}

\author{
A new relationship between heat input and IMC thickness was observed in \\ weld brazing a joint of aluminum to stainless steel and verified by hot-dip aluminizing
}

\author{
BY H. HE, W. GOU, S. LIN, C. YANG, AND P. F. MENDEZ
}

\begin{abstract}
The relationship between heat input, microstructures, and mechanical properties was studied in the gas tungsten arc (GTA) weld brazing process of aluminum alloy and stainless steel dissimilar metals with a pure aluminum core wire (ERIIOO). The mechanisms involved were further revealed by hot-dip aluminizing experiments. The intermetallic compounds (IMCs) of the brazing interface consisted of a thin layer of $\eta-\mathrm{Fe}_{2} \mathrm{Al}_{5}$ next to the steel, and a thick layer of $\theta$ $\mathrm{Fe}_{4} \mathrm{Al}_{13}$ adjacent to the $\mathrm{Al}$ joint, surrounded by eutectic identified to be $\mathrm{Al}-\mathrm{FeAl}_{6}$ and $\mathrm{Al}-\mathrm{Fe}_{2} \mathrm{Al}_{9}$ distributed uniformly in the weld metal. With increasing heat input, the total thickness of the IMCs decreased first, reaching a minimum value of $3.5 \mu \mathrm{m}$, and then increased. The decrease in IMC thickness with heat input was observed for the first time and had never been reported before in welding or brazing processes. The joint strength increased to a maximum value of $238 \mathrm{MPa}$ and then declined, suggesting an inverse relationship between IMC thickness and joint strength. The results of the hot-dip aluminizing, regarding the relationship between IMC thickness and temperature, were consistent with the change of IMC thickness in the welds. A possible mechanism in action is that interfacial kinetics and thermodynamics play a role in the dissolution and decomposition of the thick layer of $\theta-\mathrm{Fe}_{4} \mathrm{Al}_{13}$ into the $\mathrm{FeAl}_{6}$ and $\mathrm{Fe}_{2} \mathrm{Al}_{9}$ phase. Promoting the IMC dissolution or decomposition by adjusting welding procedures is a promising new way to control the IMC growth and improve the joint strength.
\end{abstract}

\section{KEYWORDS}

- Steel • Aluminum • Weld Brazing • Hot-Dip Aluminizing - Intermetallic

\section{Introduction}

With the introduction of emission standards, energy saving and environmental preservation require the reduction of vehicle weight and an improvement of strength-to-weight ratio. Replacement of some steel parts with components made of lightweight alloys, including titanium, aluminum, and magnesium, can be an effective method of lowering a total weight of an assembly. In addition, hybrid structures consist of different materials, and employ properties of both involved compounds, providing a unique set of physical and mechanical properties in one item, and offering design engineers flexibility in many situations. Therefore, there are increasing challenges and demands from many engineering industries for reliable techniques, which can be applied to the joining of dissimilar metals and alloys, such as aluminumtitanium, aluminum-steel, magnesium-steel, and so forth (Ref. 1).

Steel and aluminum alloys rank among the most popular engineering materials because they provide good properties at a low material cost in many applications (Ref. 2). The combination of high strength, good creep resistance, and formability of steel, together with low density, enhanced thermal conductivity, and good corrosion resistance of aluminum, has a great potential to meet the increasing engineering demands. Applications of the aluminum-steel hybrid structures are the aluminum superstructures joined to steel hulls, aluminum to steel tailor-welded blanks for automotive components, and aluminum-stainless steel valve assemblies used in rocket motors (Refs. 3, 4).

However, it is well known that joining those dissimilar metals into a durable component is difficult, mainly due to the different properties of the base materials and the rapid formation of brittle intermetallic phases in the interfacial zone. For the case of joining aluminum alloys to steels, a large difference in melting temperatures of aluminum $\left(570^{\circ}-660^{\circ} \mathrm{C}\right)$ and steel $\left(1350^{\circ}-1535^{\circ} \mathrm{C}\right)$, strongly differing thermal conductivities and thermal expansions of those metals, and low mutual solubility are creating residual stress, distortion, and a variety of welding defects. Furthermore, metallurgically, chemical reactions and interdiffusion processes associated with the joining processes lead to the formation of a series of brittle intermetallic compounds 

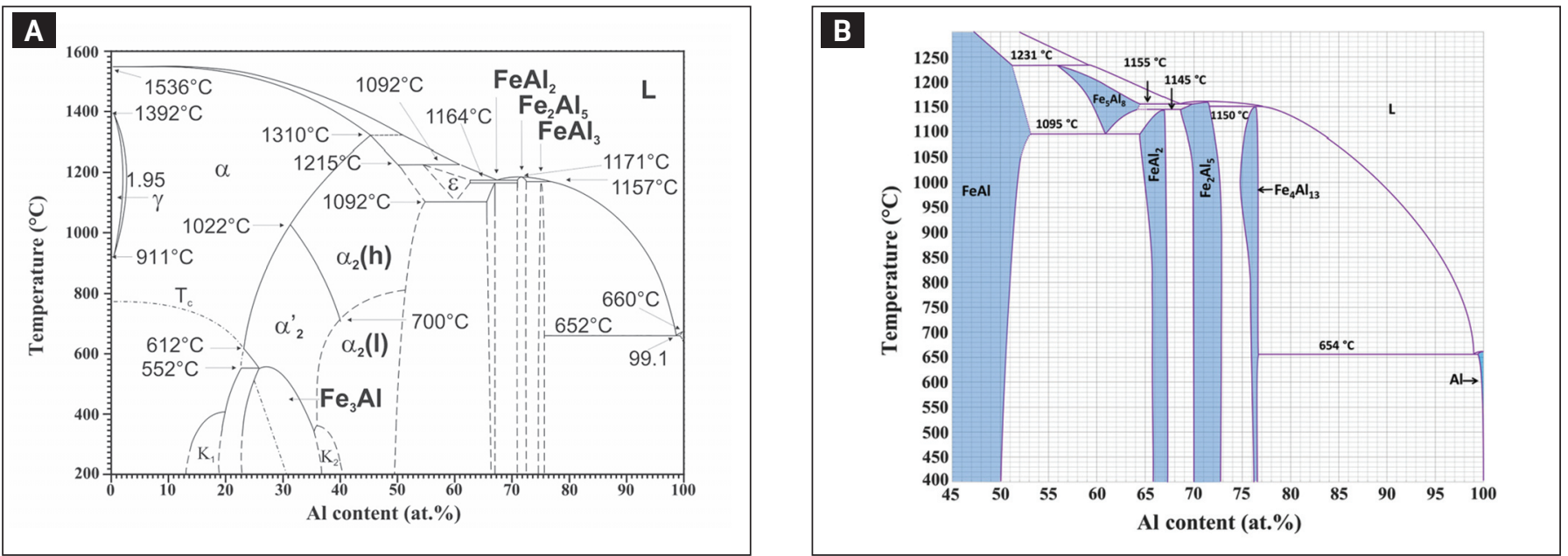

Fig. 1 - Fe-Al phase diagrams: A - Overall (Ref. 9); B - Al-rich part (Ref. 6).
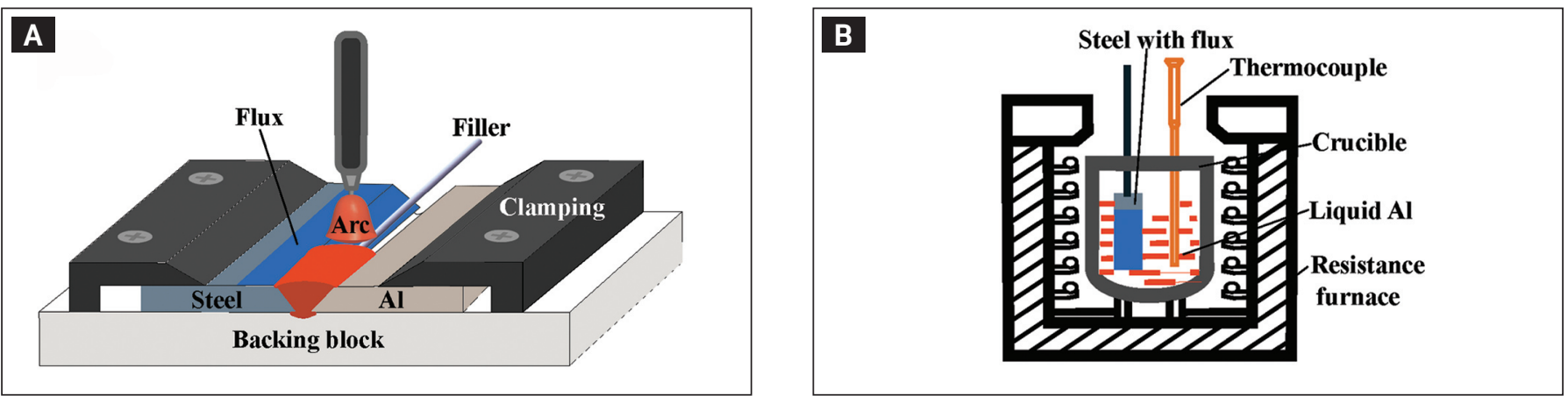

Fig. 2 - Experimental processes: A - Weld brazing; B - hot-dip aluminizing.

(IMCs) at the aluminum/steel interface. The presence of IMCs ensures metallurgical bonding between the aluminum and steel, but on the other hand, too much brittle IMCs can be detrimental to the properties of joints. Therefore, it is critical to keep the thickness of IMCs in the range of a few micrometers to avoid a brittle and easy-to-crack interface.

Possible IMCs at the steel/aluminum interface include stable and metastable phases such as $\mathrm{Fe}_{3} \mathrm{Al}, \mathrm{FeAl}, \mathrm{Fe}_{5} \mathrm{Al}_{8}, \mathrm{FeAl}_{2}$, $\mathrm{Fe}_{2} \mathrm{Al}_{5}, \mathrm{FeAl}_{3}$, and $\mathrm{Fe}_{4} \mathrm{Al}_{13}$ (Refs. 5, 6). $\mathrm{Fe}_{5} \mathrm{Al}_{8}$ is a high-temperature phase, and $\mathrm{FeAl}_{2}$ often grows so slowly that it is hardly visible or totally missing (Ref. 6). For some phases, such as $\mathrm{FeAl}_{3}$ and $\mathrm{Fe}_{4} \mathrm{Al}_{13}$, there is no general agreement on their formula, as shown in the phase diagrams of Fig. 1. The phase $\mathrm{Fe}_{4} \mathrm{Al}_{13}$ originally was denoted as $\mathrm{FeAl}_{3}$ in the historic literature until Grin et al. (Ref. 7) published their structure refinement of the $\mathrm{Fe}_{4} \mathrm{Al}_{13}$ phase in 1994. Recently, density functional theory calculations showed the stability of the $\mathrm{Fe}_{4} \mathrm{Al}_{13}$ phase and predicted $\mathrm{Fe}_{4} \mathrm{Al}_{13}$ was the only stable composition (Ref. 8).
The control of IMCs can be successfully achieved by solidstate joining processes, including mechanical clinching (Ref. 10), self-piercing riveting (Ref. 11), diffusion bonding (Refs. 12, 13), explosive welding (Ref. 14), magnetic pulse welding (Ref. 15), friction welding (Refs. 16, 17), and friction stir welding (Refs. 18, 19). The joints formed by these solidstate joining processes are based on solid-solid reaction and experience a low-temperature thermal cycle, which is beneficial for suppressing the IMCs. However, compared with solid-state welding, it is more difficult to suppress the IMCs in thermal joining processes based on solid-liquid interface reaction, such as brazing (Ref. 20), electron beam (Ref. 21), laser (Ref. 22), and arc weld brazing processes (Refs. 23, 24). Massive formation of brittle IMCs is a critical issue of these thermal joining processes, especially those with higher process temperatures and longer interaction times.

In the weld brazing processes of Al-Fe dissimilar metals, two main IMCs have been reported in most cases: $\eta-\mathrm{Fe}_{2} \mathrm{Al}_{5}$

Table 1-Chemical Compositions of Base and Filler Metals, wt-\%

\begin{tabular}{ccccccccccccc} 
& $\mathrm{C}$ & $\mathrm{Mn}$ & $\mathrm{Mg}$ & $\mathrm{Al}$ & $\mathrm{Si}$ & $\mathrm{Cu}$ & $\mathrm{Zn}$ & $\mathrm{Ti}$ & $\mathrm{Ni}$ & $\mathrm{Cr}$ & $\mathrm{Fe}$ \\
\hline SUS321 & 0.12 & 2 & - & - & 1 & - & - & 0.2 & $8-10$ & $17-19$ & Bal. \\
5A06 & - & $0.5-0.8$ & $5.8-6.8$ & Bal. & 0.4 & 0.1 & 0.2 & 0.1 & - & - & 0.4 \\
ER1100 & - & 0.05 & - & Bal. & (व) & $0.05-0.2$ & 0.1 & - & - & - & (व) \\
\hline
\end{tabular}

(a) Si plus Fe 0.95 


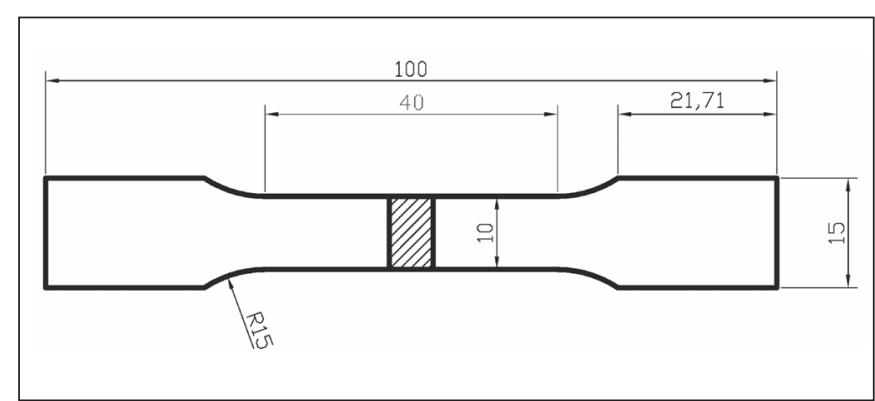

Fig. 3 - Schematic of tensile test samples.

and $\theta-\mathrm{FeAl}_{3}$ (also referred to as $\mathrm{Fe}_{4} \mathrm{Al}_{13}$ ). With using base metals of galvanized and low-alloy steels, the $\mathrm{Fe}_{2} \mathrm{Al}_{5}$ dominates the interface IMC, and its growth is governed by the diffusion mechanism (Refs. 25-27). In such case, the thickness of the IMC increases with increasing heat input. Reducing heat input is an effective way to control the growth of the IMC layer. It has been proved in many joining methods, such as traditional arc weld brazing (Refs. 24, 28, 29), cold metal transfer weld brazing (Refs. 30, 31), laser weld brazing (Refs. 32-36), electron beam welding (Ref. 37), and laser-arc hybrid welding (Ref. 38). Nevertheless, with employing base metal of stainless steel, the $\mathrm{FeAl}_{3}\left(\mathrm{Fe}_{4} \mathrm{Al}_{13}\right)$ becomes the dominant IMC instead of the $\mathrm{Fe}_{2} \mathrm{Al}_{5}$. Previous reported kinetics of the $\theta$ phase are based on interface reactions of pure iron or carbon steel with molten aluminum. Their conclusions about the kinetics vary between diffusion (Ref. 25), interface reaction (Ref. 26), precipitation, and reaction diffusion (Ref. 27), which provided confused information of the growth mechanism of the $\theta$ phase. Dybkov proposed a point that the growth of an IMC layer at the solid-liquid interface and its dissolution into the liquid aluminum take place simultaneously (Ref. 39). It is promising to reveal the kinetic of the $\theta$ phase and provide a potential approach of suppressing an IMC layer by increasing heat input in a reasonable range to promote the dissolution of the IMC.

In this study, considering both the formation and decomposition of the interfacial IMCs, the relationship between heat input, microstructures, and mechanical behavior of aluminum-stainless steel gas tungsten arc (GTA) weld brazing a joint were studied. Furthermore, hot-dip aluminizing of stainless steel was conducted to reveal the influence of reaction temperature and time on IMCs. The results of weld brazing and hot-dip aluminizing were compared, and the mechanisms involved were analyzed.

\section{Experimental}

\section{Weld Brazing Experiments}

Base materials for this study included a 3.0-mm-thick 5 A06 aluminum (similar to 5456 in the United States) and SUS321 stainless steel sheets. The filler was an ER1100 pure aluminum welding wire with a diameter of $1.6 \mathrm{~mm}$. The chemical compositions of the base and filler metals are listed in Table 1. The solidus and liquidus temperatures of the ER1100 filler metal are $643^{\circ}$ and $657^{\circ} \mathrm{C}$, respectively. The solidus and liquidus temperatures of the 5A06 aluminum
Table 2 - Analysis of EDS (at.-\%)

\begin{tabular}{ccccc} 
Elements & $\mathrm{Al}$ & $\mathrm{Fe}$ & $\mathrm{Cr}$ & $\mathrm{Ni}$ \\
\hline $\mathrm{Fe}_{2} \mathrm{Al}_{5}$ & 71.93 & 21.17 & 5.05 & 1.85 \\
$\mathrm{Fe}_{4} \mathrm{Al}_{13}$ & 77.11 & 17.04 & 4.21 & 1.64 \\
\hline
\end{tabular}

base metal are $570^{\circ}$ and $638^{\circ} \mathrm{C}$, respectively (Ref. 40). The solidus and liquidus temperatures of the SUS 321 stainless steel base metal are $1398^{\circ}$ and $1446^{\circ} \mathrm{C}$, respectively.

The size of the specimen was 100 by $50 \mathrm{~mm}$, with a $45-\mathrm{deg}$, single- $V$ groove, in both the steel and aluminum side. The surfaces of the steel and aluminum base metals were cleaned by abrasive papers and a scraper knife (a tool for cleaning the aluminum surface), respectively, and then rinsed and cleaned by ethanol. A modified flux layer $\left(\mathrm{KAlF}_{4}+\mathrm{Al}\right.$ powder $)$, approximately $0.2-0.5 \mathrm{~mm}$ thick, was coated on the groove, front, and back surfaces of the steel in a $10 \mathrm{~mm}$ width to prevent oxidization of the steel and improve wettability of the molten aluminum on it. Butt joint GTA weld brazing experiments of aluminum to steel were carried out using a standard welding power source. The welding parameters were an alternating current (AC) square wave of $100 \mathrm{~Hz}$, a 4:1 AC balance, an arc length of 3.0-4.0 mm, a welding speed of $150 \mathrm{~mm} / \mathrm{min}$, and an argon gas flow rate of $8-10 \mathrm{~L} / \mathrm{min}$. The weld brazing process is illustrated in Fig. 2A.

To analyze the thermal cycling curves at the interfaces, a conduction-based, heat-transfer finite element method (FEM) model with the Marc software was used as a coarse approximation of temperature fields at the $\mathrm{Fe} / \mathrm{Al}$ interface during weld brazing. A general double-ellipsoid welding heat source proposed by Goldak et al. was employed, in which heat flux is distributed in a Gaussian manner throughout the heat source's volume and can accurately simulate different types of welding processes with shallow and deep penetration (Ref. 41). An elements birth-death technique was also applied in this study. The elements in the welding power source are considered as "dead" elements; this was achieved by multiplying their conductivity or other analogous quantities by a severe reduction. When the welding joint is generated, the corresponding elements start to be considered as "live" elements by allowing their properties to return to original values (Ref. 42). The FEM model was verified by a thermocouple instrument made in-house.

\section{Hot-Dip Aluminizing Experiments}

The SUS321 stainless steel ( 40 by $10 \mathrm{~mm}$ ) and pure aluminum ingots (50 $\mathrm{mm}$ in diameter and $50 \mathrm{~mm}$ in length) were employed to conduct hot-dip aluminizing experiments. Before dipping, the surface of the stainless steel and aluminum ingot were cleaned the same as the weld brazing process. The $\mathrm{KAlF}_{4}$ flux was coated on the steel surface to prevent oxidization of the steel and improve the wettability of the molten aluminum on it.

The hot-dipping system consisted of a box-type resistance furnace, an alumina crucible with an inner diameter of $75 \mathrm{~mm}$, and a thermocouple. The steel sheets were immersed in molten aluminum for $4-10 \mathrm{~s}$, at $700^{\circ}-1000^{\circ} \mathrm{C}$, respectively. The reaction temperatures were measured by the 

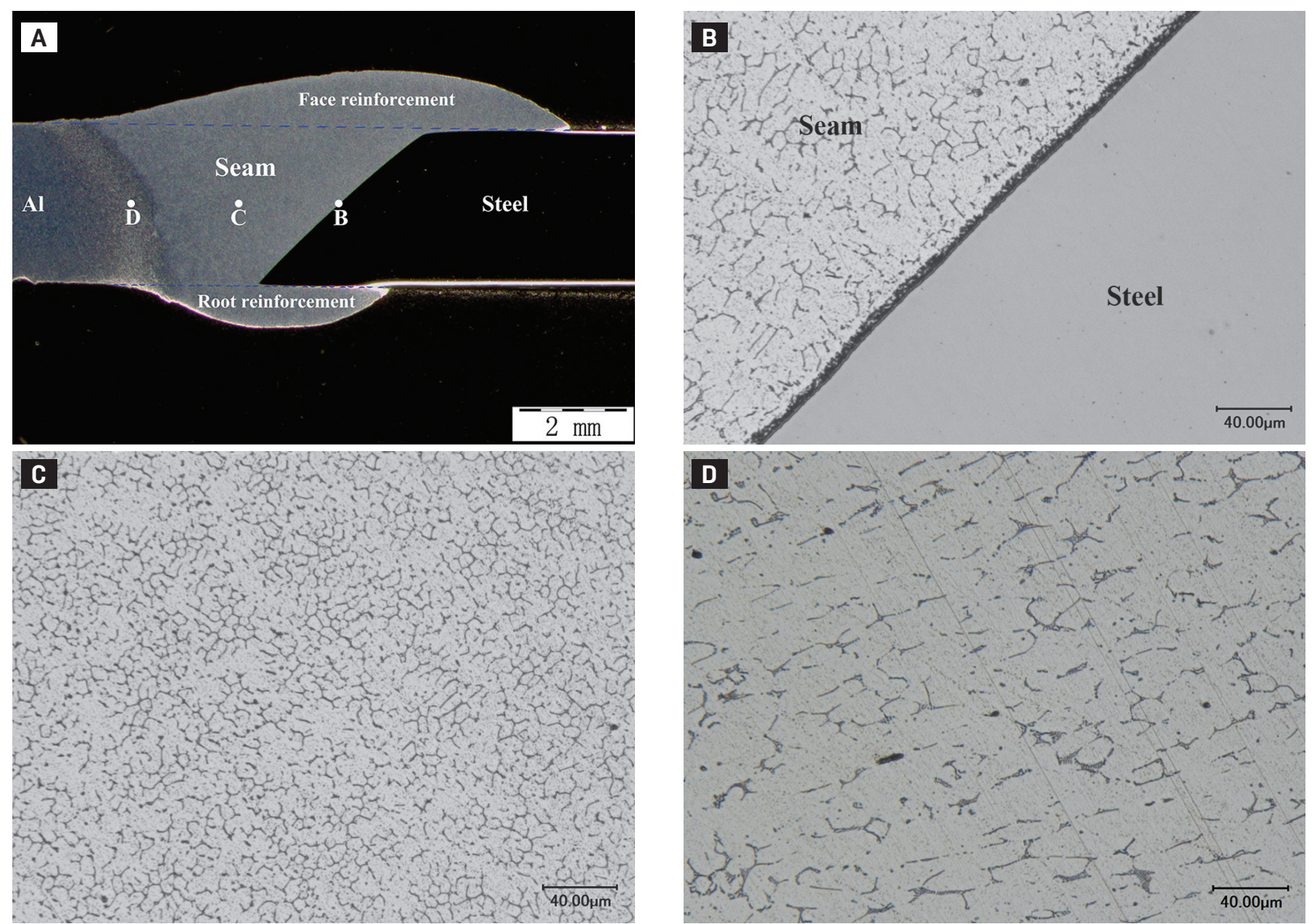

Fig. 4 - Typical transverse cross section and optical micrographs of the aluminum-steel butt joint: A - Typical cross section; B optical micrograph of position $B ; C$ - optical micrograph of position $C ; D$ - optical micrograph of position $D$.

thermocouple and were monitored in real time by a temperature controller. The hot-dip aluminizing process is illustrated in Fig. 2B.

\section{Characterization and Tensile Testing}

After welding or dipping experiments, the microstructure and IMC composition at the interfaces were examined by optical microscope, scanning electron microscopy (SEM), and energy-dispersive $\mathrm{x}$-ray spectrometer (EDS). A thin-foil specimen for transmission electron microscope (TEM) was extracted from the interface area using a focused ion beam (FIB) system. The IMCs were identified by TEM. The SEM images were processed using an image processing software to obtain the areas by selecting the IMCs with a Magnetic Lasso Tool and further calculate the thicknesses of the IMCs, and also to obtain the proportion of microstructures in the weld joint. Tensile tests were conducted using an INSTRON-5569 testing machine with a loading speed of $0.5 \mathrm{~mm} / \mathrm{min}$. The dimensions of tensile test samples are shown in Fig. 3. All the area/thickness measurements and tensile tests were performed in triplicate with different samples.

\section{Results}

\section{Macrostructure and Microstructure of the Weld Brazing Joint}

Figure 4A presents typical sectional views of the weld brazing joint. The aluminum alloy, which has a low melting point, is fused and mixes with the liquid filler metal to produce a welded joint with an obvious weld interface, while the stainless steel keeps in solid state and reacts with liquid aluminum to form a brazing interface. Optical micrographs of a different position in this sectional view are shown in Fig. 4B-D. A visible IMC layer formed in the steel/welded joint interface - Fig. 4B. Transition phases in the joint can be observed clearly in Fig. 4C and D, respectively.

Two IMC layers can be observed in the weld brazing interface from SEM and TEM micrographs in Fig. 5. Based on the TEM diffraction results in Fig. 5C and D, the interface intermetallic layers are identified to be a thin $\eta-\mathrm{Fe}_{2} \mathrm{Al}_{5}$ layer next to the base stainless steel and a thick $\theta-\mathrm{Fe}_{4} \mathrm{Al}_{13}$ layer close to the aluminum, consistently with the phases present in the phase diagram of Fig. 1B. The $\eta-\mathrm{Fe}_{2} \mathrm{Al}_{5}$ has an orthorhombic unit cell with $\mathrm{a}=0.7649 \mathrm{~nm}, \mathrm{~b}=0.6413 \mathrm{~nm}$, 

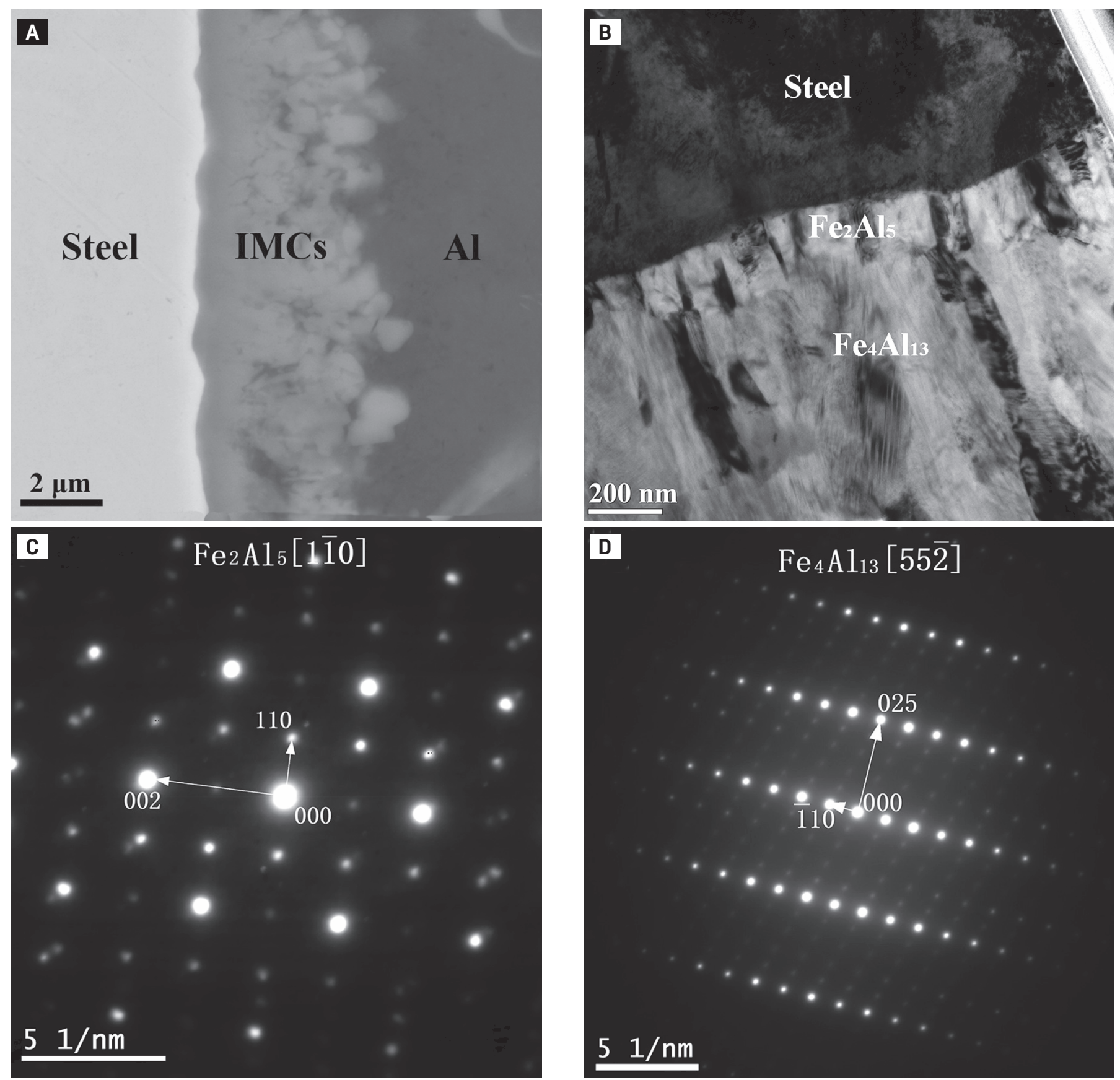

Fig. 5 - IMC morphology and TEM diffraction spots: A - SEM image; B - TEM morphology; C - TEM diffraction spot of $\mathrm{Fe}_{2} \mathrm{Al}_{5} ; \mathrm{D}-$ TEM diffraction spot of $\mathrm{Fe}_{4} \mathrm{Al}_{13}$.

and $c=0.4217 \mathrm{~nm}$ (Ref. 43). The $\theta-\mathrm{Fe}_{4} \mathrm{Al}_{13}$ phase has a monoclinic unit cell with $\mathrm{a}=1.548 \mathrm{~nm}, \mathrm{~b}=0.8083 \mathrm{~nm}, \mathrm{c}=$ $1.2476 \mathrm{~nm}$, and $\beta=107.72 \mathrm{deg}$ (Refs. 44-46). The phases in the welded joint have been identified to be $\mathrm{FeAl}_{6}$ and $\mathrm{Fe}_{2} \mathrm{Al}_{9}$, as shown in Fig. 6. The $\mathrm{FeAl}_{6}$ has an orthorhombic unit cell with $\mathrm{a}=0.646 \mathrm{~nm}, \mathrm{~b}=0.744 \mathrm{~nm}$, and $\mathrm{c}=0.878 \mathrm{~nm}$ (Refs. 47, 48). The $\mathrm{Fe}_{2} \mathrm{Al}_{9}$ has a monoclinic lattice of the $\mathrm{Co}_{2} \mathrm{Al}_{9}$ type with parameters $\mathrm{a}=0.8598 \mathrm{~nm}, \mathrm{~b}=0.6271 \mathrm{~nm}, \mathrm{c}=$ $0.6207 \mathrm{~nm}$, and $\beta=94.66 \mathrm{deg}$ (Ref. 49).

The composition of the intermetallic layers was measured in at least three points in each IMC layer using EDS of the TEM foils, and is summarized in Table 2 . The results show that a small quantity of $\mathrm{Cr}$ and $\mathrm{Ni}$ is contained in the two IMCs. The IMCs are solid solution based upon the $\mathrm{Fe}_{4} \mathrm{Al}_{13}$ and $\mathrm{Fe}_{2} \mathrm{Al}_{5}$, and can also be expressed as ( $\mathrm{Fe}, \mathrm{Cr}$, $\mathrm{Ni})_{4} \mathrm{Al}_{13}$ and (Fe, $\mathrm{Cr}, \mathrm{Ni}_{2} \mathrm{Al}_{5}$, respectively (Ref. 50).

\section{Effect of Heat Input on Microstructure}

To obtain a reliable joint of aluminum and steel with satisfactory appearance, a reasonable range of welding current should be adopted to ensure the fusion of the base aluminum and filler without overheating and melting of the base steel. For the present experiments, the reasonable 

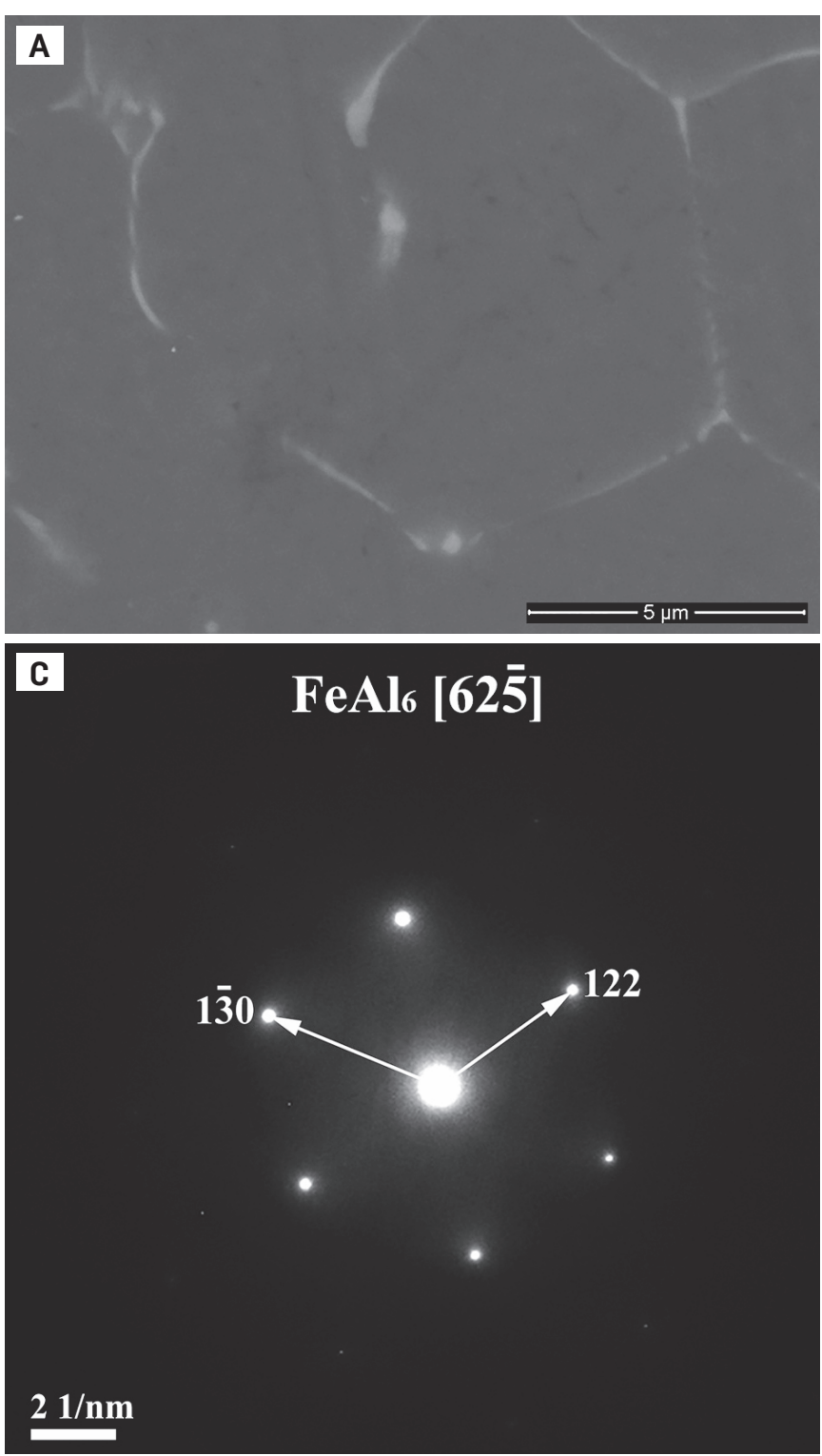
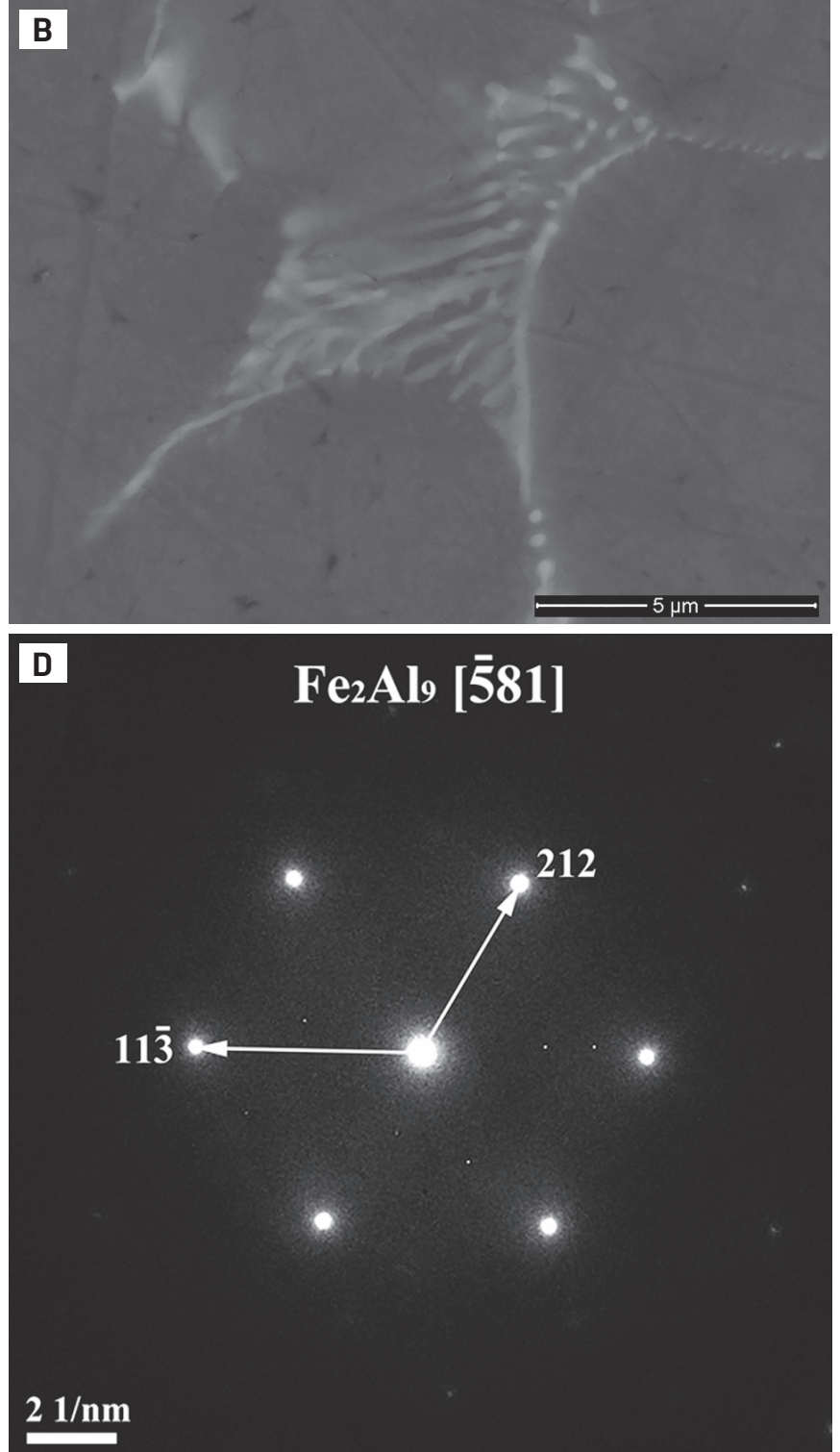

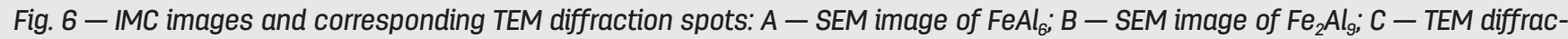
tion spot of $\mathrm{FeAl}_{6}$; $\mathrm{D}-\mathrm{TEM}$ diffraction spot $\mathrm{Fe}_{2} \mathrm{Al}_{9}$.

welding current is from 86.5 to $120 \mathrm{~A}$. If the welding current is lower than $86.5 \mathrm{~A}$ or higher than $120 \mathrm{~A}$, welding defects such as incomplete fusion, incomplete penetration, undercutting, and melt-through will occur.

SEM and TEM images of the interfacial IMCs are shown in Figs. 7 and 8. With increasing heat input, the total thicknesses of IMCs at the interface changed significantly, while the thicknesses of $\mathrm{Fe}_{2} \mathrm{Al}_{5}$ kept in approximately $200 \mathrm{~nm}$ under a different welding current. Two distinct periods can be observed in Fig. 9. With the increase in welding current from 86.5 to 120 $\mathrm{A}$, the thickness of IMCs decreased first, reached a minimum value of $3.5 \mu \mathrm{m}$ at $110 \mathrm{~A}$, and then increased.

SEM images of the microstructures in the weld joints under different welding currents are shown in Fig. 10. The proportion of $\mathrm{FeAl}_{6}$ and $\mathrm{Fe}_{2} \mathrm{Al}_{9}$ in the weld joints are illustrated in Fig. 11. With increasing welding current, the proportion of $\mathrm{FeAl}_{6}$ and $\mathrm{Fe}_{2} \mathrm{Al}_{9}$ in the weld increased constantly.

\section{Effects of Heat Input on Joint Properties}

Tensile tests were carried out to evaluate the joint tensile strength. The results with and without reinforcement are shown in Fig. 12. The tensile strength of the joint with reinforcement increased from 172 to $238 \mathrm{MPa}$ between 86.5 and $110 \mathrm{~A}$, then decreased to $173 \mathrm{MPa}$ between 110 and $120 \mathrm{~A}$. The joint strength without reinforcement increased from 117 to $158 \mathrm{MPa}$ between 86.5 and $110 \mathrm{~A}$, then decreased to $102 \mathrm{MPa}$ between 110 and $120 \mathrm{~A}$. The existence of reinforcement increases the joint strength by $47-70 \%$, yet does not influence the strength variation tendencies. The optimal weld brazing appearance of an aluminum-steel weld always has face and root reinforcement (Refs. 39, 51). The existence of the reinforcement increases the joint thickness and enlarges the brazing area. These two aspects both positively impact the joint strength. 


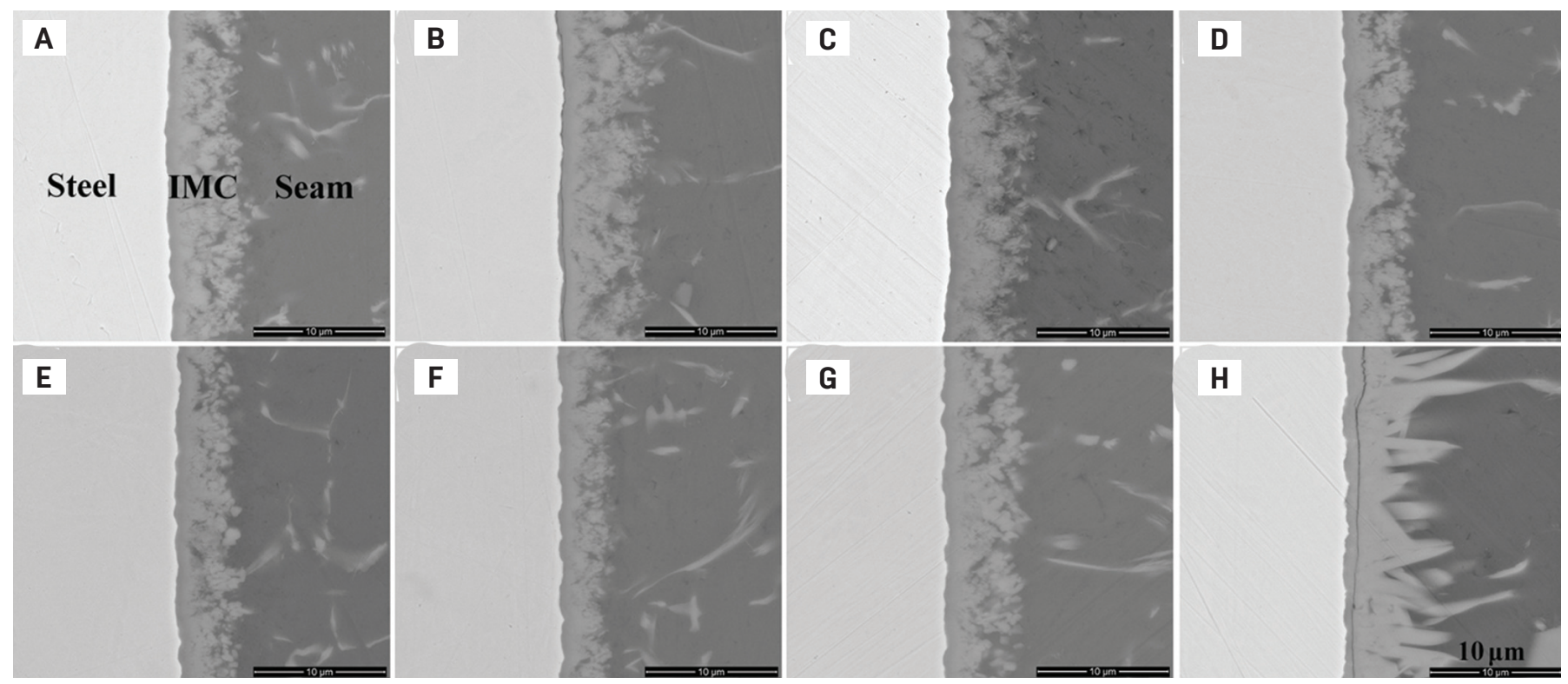

Fig. 7 - SEM images of the IMCs under different welding currents: $A-86.5 A ; B-90 A ; C-95 A ; D-100 A ; E-105 A ; F-110 A$; G $-115 \mathrm{~A} ; \mathrm{H}-120 \mathrm{~A}$.
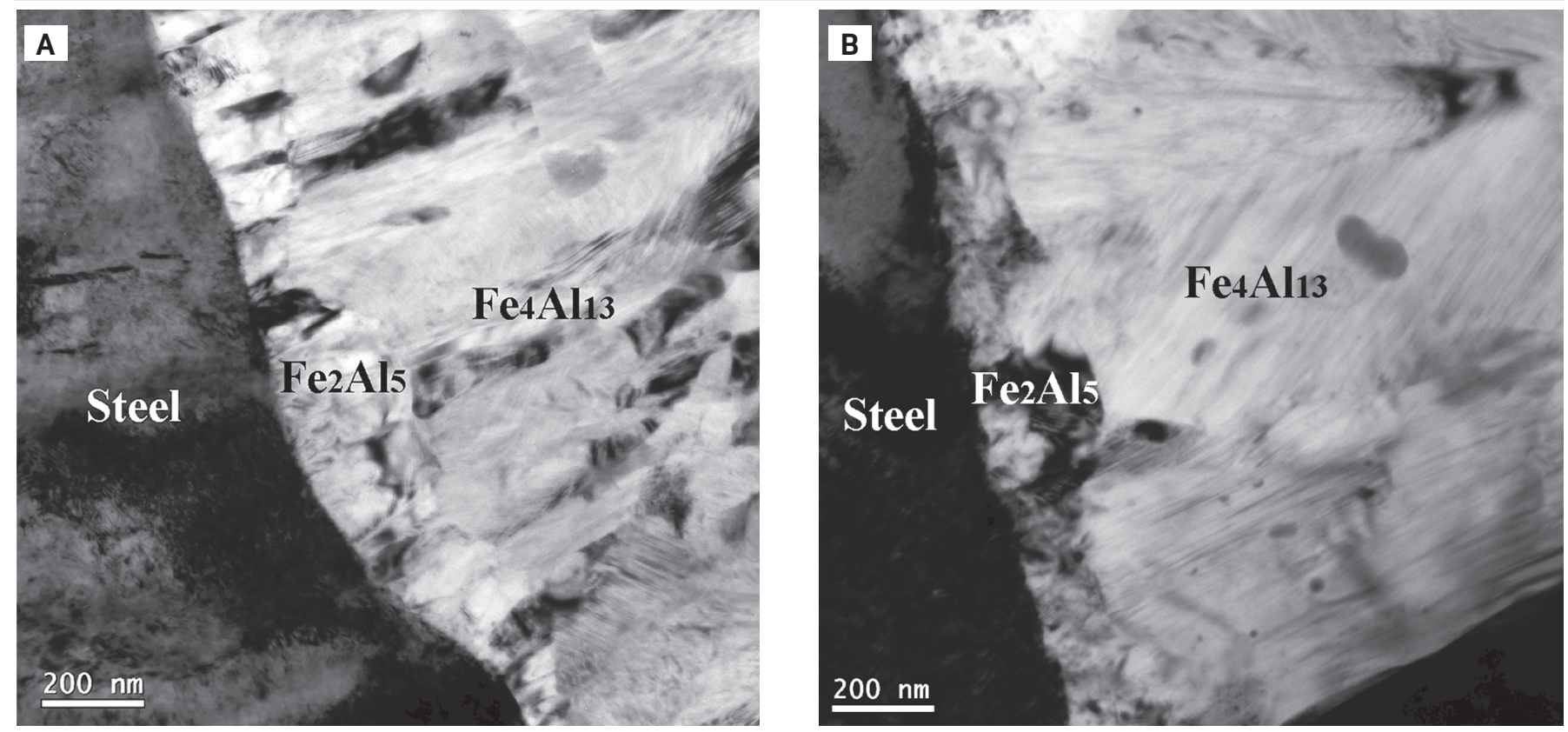

Fig. 8 - TEM morphology of $\mathrm{Fe}_{2} \mathrm{Al}_{5}$ under different welding currents: $\mathrm{A}-90 \mathrm{~A} ; \mathrm{B}-110 \mathrm{~A}$.

\section{Temperature Field and Thermal Cycles of the Interfaces}

Figure 13 shows a typical temperature field of the GTA weld brazing process between aluminum and stainless steel. The temperature distribution exhibits an obviously asymmetric characteristic. Because the heat conductivity of the $\mathrm{Al}$ alloy outclasses that of stainless steel, the high-temperature area at the $\mathrm{Al}$ side is wider than the steel side. Figure 14 shows thermal cycle curves extracted from FEM simulation results, corresponding to the point 4 (in Fig. 13B) for the joints with different welding currents. The change in welding current influences the thermal cycles of the interfaces. With the increase in welding current from 90 to $120 \mathrm{~A}$, as illustrated in Table 3, peak temperature at the interface increased from $736^{\circ}$ to $1004^{\circ} \mathrm{C}$, and the solid steel-liquid aluminum reaction time increased from 4.59 to $10.10 \mathrm{~s}$. As the liquid pool is a mixture of ER1100 filler and 5A06 base alloy, the liquidus temperature in this study was estimated to be approximately $650^{\circ} \mathrm{C}$ based on the liquid temperatures of the aforementioned materials $\left(657^{\circ} \mathrm{C}\right.$ of ER1100 and $638^{\circ} \mathrm{C}$ of 5A06).

\section{Hot-Dip Aluminizing}

The hot-dipping experiments were conducted at different temperatures, estimated by the FEM modeling of the weld 


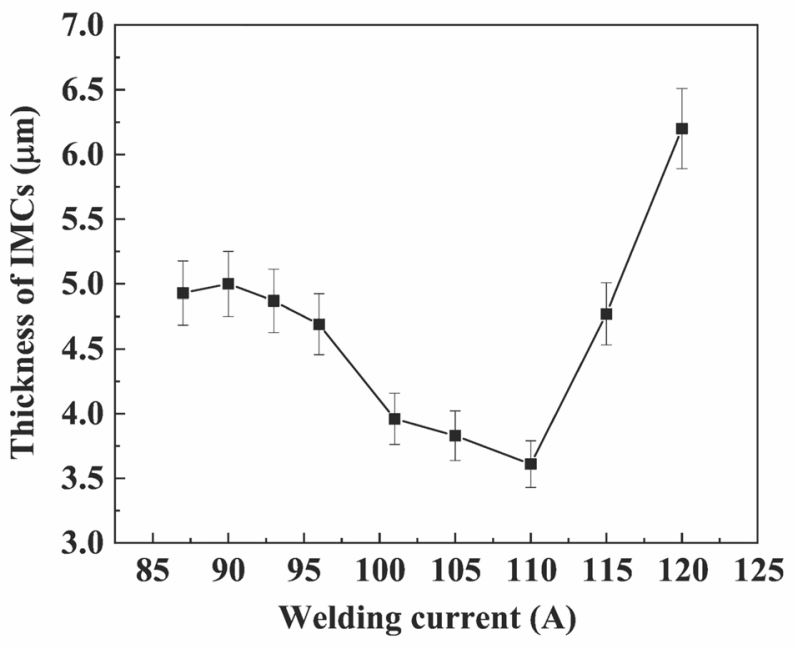

Fig. 9 - Relationship between welding current and thicknesses of the IMCs.

brazing process. The dominated IMC of hot-dipping interfaces is $\mathrm{Fe}_{4} \mathrm{Al}_{13}$, similar to the weld brazing interface. The changes in $\mathrm{Fe}_{4} \mathrm{Al}_{13}$ thickness with temperature and time are shown in Fig. 15. The relationship between the hot-dipping temperature $\left(700^{\circ}-1000^{\circ} \mathrm{C}\right)$ and the thickness of $\mathrm{Fe}_{4} \mathrm{Al}_{13}$ in 5-10 s are illustrated in Fig. 15B. With the increase in reaction time, the thickness of the IMCs increased linearly at all four temperatures. The results of the hot-dip aluminizing at different temperatures showed results consistent with the weld brazing interfaces, with thick IMC layers at $700^{\circ} \mathrm{C}$, thinner at intermediate temperatures $\left(800^{\circ}\right.$ and $\left.900^{\circ} \mathrm{C}\right)$, and thicker again at $1000^{\circ} \mathrm{C}$.

\section{Discussion}

\section{Microstructure of Intermetallics and Weld Bead}

In this work, the two layers $\left(\eta-\mathrm{Fe}_{2} \mathrm{Al}_{5}\right.$ and $\left.\theta-\mathrm{Fe}_{4} \mathrm{Al}_{13}\right)$ between aluminum and stainless steel were observed clearly with the help of the FIB technique. As already mentioned in the introduction and illustrated in Fig. 1, there are other IMCs, such as $\mathrm{Fe}_{5} \mathrm{Al}_{8}$ and $\mathrm{FeAl}_{2}$, that may be present during the process but are not found in the final microstructures likely due to thermo or kinetic reasons. Thermodynamically, $\mathrm{Fe}_{4} \mathrm{Al}_{13}$ is more stable than $\mathrm{FeAl}_{3}$ (Ref. 8), and it is the one observed in this work. The two-layer structures at the interface are similar to other published results, including the weld brazing process of carbon steel (Refs. 36, 52), lowalloyed steel (Ref. 37), and high-strength steel (Ref. 53) to aluminum, as well as hot-dip aluminizing of low-carbon steels (Refs. 8, 54). However, in the weld brazing interfaces between aluminum and stainless steel, only the $\theta-\mathrm{Fe}_{4} \mathrm{Al}_{13}$ phase was reported in previous studies, possibly due to the limitation of the sample preparation technique of TEM (Refs. 55, 56).

The $\mathrm{Fe}_{4} \mathrm{Al}_{13}$ layer dominates the interface microstructure
Table 3 - Peak Temperature and Solid-Liquid Reaction Time Under Different Welding Currents

\begin{tabular}{lcccc} 
& $90 \mathrm{~A}$ & $100 \mathrm{~A}$ & $110 \mathrm{~A}$ & $120 \mathrm{~A}$ \\
\hline Peak temperature at interface $\left({ }^{\circ} \mathrm{C}\right)$ & 736 & 837 & 920 & 1004 \\
Solid-liquid reaction time $(\mathrm{s})$ & 4.59 & 7.06 & 8.64 & 10.10 \\
& & & & \\
\hline
\end{tabular}

in this research, which is different from carbon steels and $\mathrm{Fe}-\mathrm{Cr}$ alloys. The dominant IMCs of a mild steel and a $\mathrm{Fe}-\mathrm{Cr}$ alloy are $\mathrm{Fe}_{2} \mathrm{Al}_{5}$. The existence of $\mathrm{Cr}$ in a steel can reduce the thickness of $\mathrm{Fe}_{2} \mathrm{Al}_{5}$ (Ref. 57). In contrast, the main IMC of Fe-Ni and Fe-Cr-Ni alloy is $\mathrm{Fe}_{2} \mathrm{Al}_{7}$ or $\mathrm{FeAl}_{3}$, instead of $\mathrm{Fe}_{2} \mathrm{Al}_{5}$. A possible reason is that the addition of $\mathrm{Ni}$ in a steel can change the dominant product of the interface from $\mathrm{Fe}_{2} \mathrm{Al}_{5}$ to $\mathrm{Fe}_{2} \mathrm{Al}_{7}, \mathrm{FeAl}_{3}$, or $\mathrm{Fe}_{4} \mathrm{Al}_{13}$ (Refs. 50, 58, 59).

The TEM analysis shows the presence of $\mathrm{FeAl}_{6}$ and $\mathrm{Fe}_{2} \mathrm{Al}_{9}$ intermetallics in the weld joint, as shown in Fig. 6. These are metastable intermetallics (Ref. 9) that have also been observed in rapidly chilled alloys, aged aluminum alloys, Mn-containing aluminum alloys, and interfaces between iron-chromium alloys and liquid aluminum (Refs. 57, 60,61). $\mathrm{Fe}_{2} \mathrm{Al}_{9}$ is stabilized by the presence of small amounts of impurities (Ref. 62), and it is possible that residual amounts of $\mathrm{Mn}, \mathrm{Si}, \mathrm{Cu}$, and $\mathrm{Zn}$ from the ER1100 welding wire and $\mathrm{Mg}$ from the $5 \mathrm{~A} 06$ base metal play this stabilizing role in this case.

\section{Relationship between Heat Input and IMC Thickness}

In this study, a phenomenon of decrease in IMC thickness with heat input was observed for the first time and had never been reported before in welding or brazing applications. This phenomenon is significantly different from previous results. Researchers have reported the IMC thickness increases with increasing heat input in many welding processes, including arc weld brazing (Refs. 24, 28, 31, 53), laser weld brazing (Refs. 33, 34), and electron beam welding (Ref. 37). The thickness of IMCs at the brazing interface is mainly determined by the reaction temperature and time for welding aluminum and steel. Because the thickness change of the IMC at the weld brazing interface in Fig. 9 is consistent with the results of hot-dip aluminizing at different temperatures in Fig. 15B, the reaction temperature plays a key role during IMC evolution.

\section{Comparison of Weld Brazing and Hot-Dip Aluminizing}

The behavior of IMC layer thickness with time and temperature was similar for hot-dipping and weld-brazing experiments; however, the hot-dipping experiments showed thicker layers. A possible reason for the thinner layers in weld brazing is that the molten metal flows are much stronger than in hot-dipping experiments because they experience much more intense thermal gradients and electromagnetic stirring. The increased convection might reduce the resistance to mass transfer on the boundary layer adjacent to the solidification surface. It has been observed previ- 

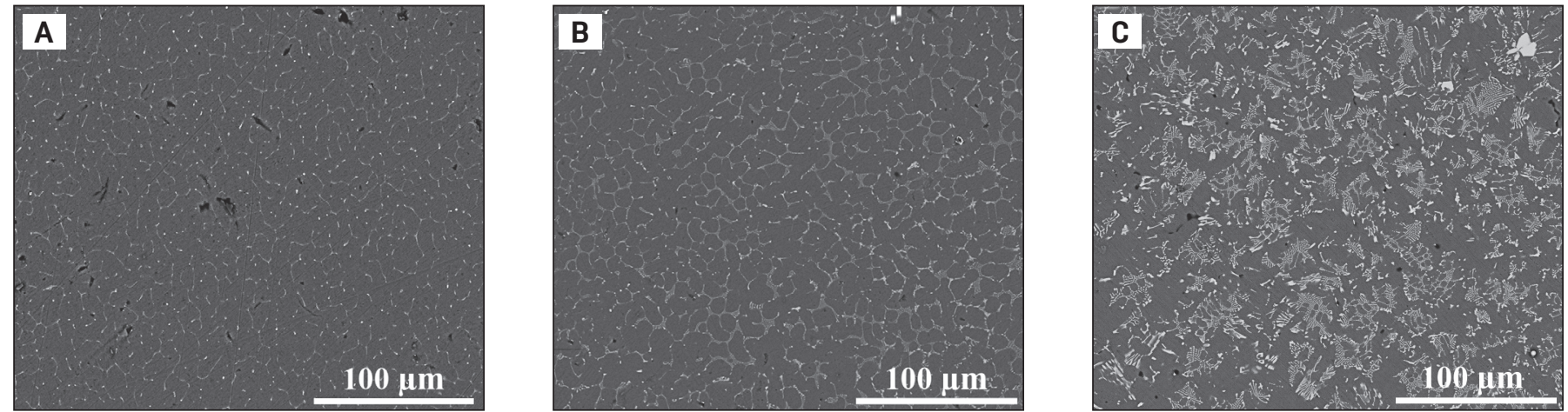

Fig. 10 - Images of $\mathrm{FeAl}_{6} / \mathrm{Fe}_{2} \mathrm{Al}_{9}$ in the welded joints under different welding currents: $\mathrm{A}-90 \mathrm{~A} ; \mathrm{B}-105 \mathrm{~A} ; \mathrm{C}-120 \mathrm{~A}$.

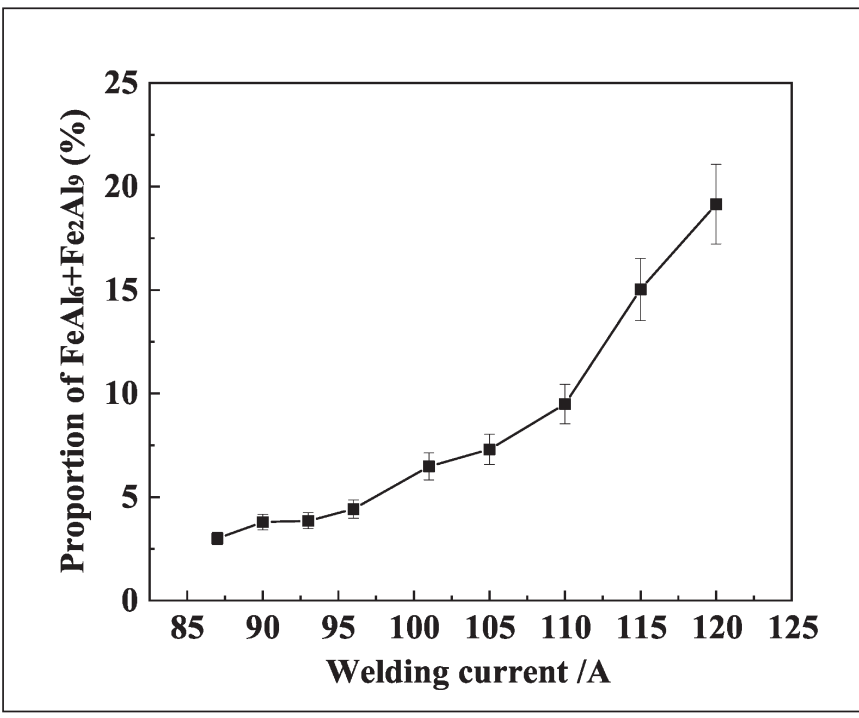

Fig. $17-$ Relationship between welding current and proportion of $\left(\mathrm{FeAl}_{6}+\mathrm{Fe}_{2} \mathrm{Al}\right)$.

ously that a rapid agitation of melt adjacent to the intermetallic layer prevents thickening of the outer IMC layer (Ref. 63). Another possible mechanism, which might coexist with that mentioned before, is the effect of electrochemical reactions at the interface. Such effects were reported to enhance the dissolution of IMC in Ni-based alloys (Refs.

64-66). Furthermore, the hot-dipped geometry provides an infinite amount of $\mathrm{Al}$ where the weld braze geometry has a limited amount of Al, which may affect the rate kinetics at the steel/filler metal interface. Another possible mechanism contributing to the observed difference in thickness is the presence of 5A06 base aluminum on the other side of the weld joint. The molten $5 \mathrm{A0} 6$ aluminum mixed into the pool during the weld brazing process possibly changes the chemical potential for the reaction on the steel side. The relative importance of these mechanisms is currently unknown and the subject of current research.

\section{Growth and Dissolution Mechanism of the IMCs}

The experiments performed suggest the growth of a compound layer at the solid-liquid interface and its dissolution into the liquid might take place simultaneously. Such behav-

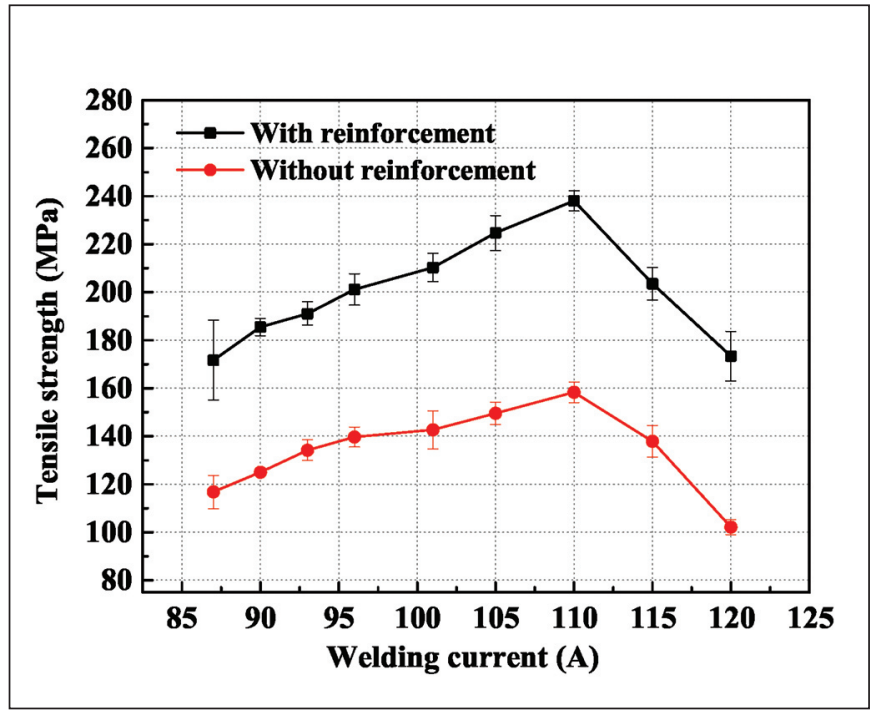

Fig. $12-$ Relationship between joint strength and welding current.

ior has already been studied in the reaction-diffusion theory field and applied to the case of growth-dissolution of the growth kinetics of the $\mathrm{Fe}-\mathrm{Al}$ intermetallics in molten aluminum (Ref. 39) for a system similar (but with essential differences) to the one in this paper.

The idealized model of Dybkov (Ref. 39) can yield some intuitive understanding into the conditions under which growth or dissolution happen in IMCs. This model accounts for bulk kinetics as volume-averaged diffusion and interface kinetics in the form of reaction rates. The model considers growth of IMCs at constant temperature, and neglects the effect of composition, stoichiometry, and internal stresses on diffusivity. The temperature dependence of thermodynamics and kinetics factors is included without problem for each case. The parameters involved in this model are typically best determined experimentally to account for the presence of metastable IMCs not present in the equilibrium phase diagram, internal stresses, secondary diffusion paths, and effect of alloying elements and impurities. When the parameters can be predicted for desired temperatures and compositions, the behavior under new conditions can be estimated.

The mathematical formulation in Ref. 39 considers the IMC layer growth by two simultaneous processes: 1) diffu- 

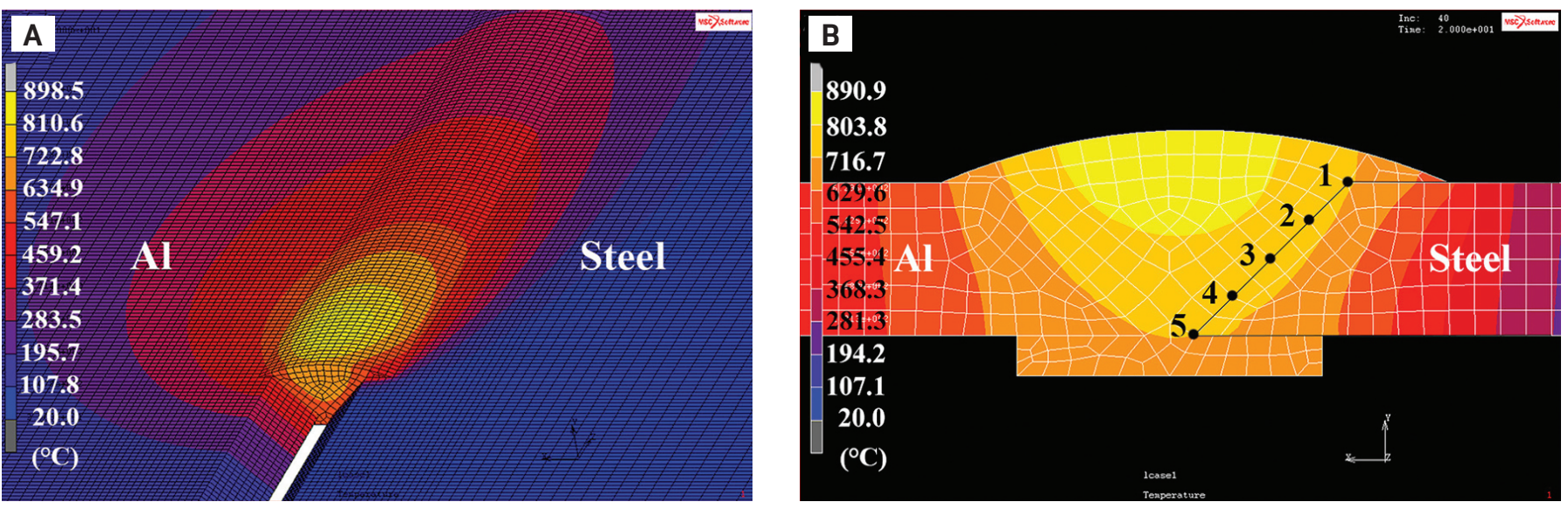

Fig. 13 - Temperature distribution of the joint: $A$ - Surface; B -cross section.

sion of atoms of the reactants across the bulk of the IMC, and 2) chemical transformations taking place at the layer interfaces with the participation of diffusing atoms of one of the components and the surface atoms of another component.

The driving force for diffusion is given by the thermodynamic activity differences across the interfaces and across the IMC layers. The thermodynamic activity depends on temperature and composition, and also affects the kinetics of diffusion and reactions at interfaces. Diffusion across the IMCs is considered driven by nonstoichiometric composition gradients, and occurring for both species ( $\mathrm{Al}$ and $\mathrm{Fe}$ ). The effect of gradients of reactants ( $\mathrm{Al}$ and $\mathrm{Fe}$ ) and alloying elements (e.g., $\mathrm{Cr}$, $\mathrm{Ni}$ ) are neglected, and the diffusivity of $\mathrm{Al}$ and Fe are considered constant within the IMC layer. The value of this time and volume-averaged diffusivity is affected by alloying elements, temperature, internal stresses, secondary diffusion paths, and so forth; for this reason, it is typically best to determine the model parameters empirically.

The model in Ref. 39 is limited to the continuous presence of two IMC layers and cannot account for transient metastable IMC layers, which are present only temporarily, and not present in the final microstructure. Because of the ordered structure of the intermetallics, nonstoichiometric mass transport can affect the balance of mass and vacancies, potentially causing Kirkendall porosity. A careful inspection in the optical and SEM microscopes of samples produced did not show evidence of porosity in or near the IMC layers.

EDS results confirmed the presence of $\mathrm{Ni}$ and $\mathrm{Cr}$ in the IMCs consistently with a substitution mechanism of $\mathrm{Cr}$ and $\mathrm{Ni}$ for Fe (Ref. 67).

Other differences between Ref. 39 and the weld brazing experiments performed is that dissolution happens into a fixed pool of liquid that is gradually enriched in solute (in this case, Fe in solution in $\mathrm{Al}$ ). This feature needs to be modified, because in the case of weld brazing, the continuously advancing weld pool reaches a steady state in Fe content, not a continuous enrichment. This modification is easy to make, turning the exponential term into an appropriate constant. For the case of stainless steel, another modification needed to the model is that partition between $\mathrm{Fe}, \mathrm{Cr}$, and $\mathrm{Ni}$ at the interface involves phenomena that must be added to this model. The diffusion resistance of the gradient

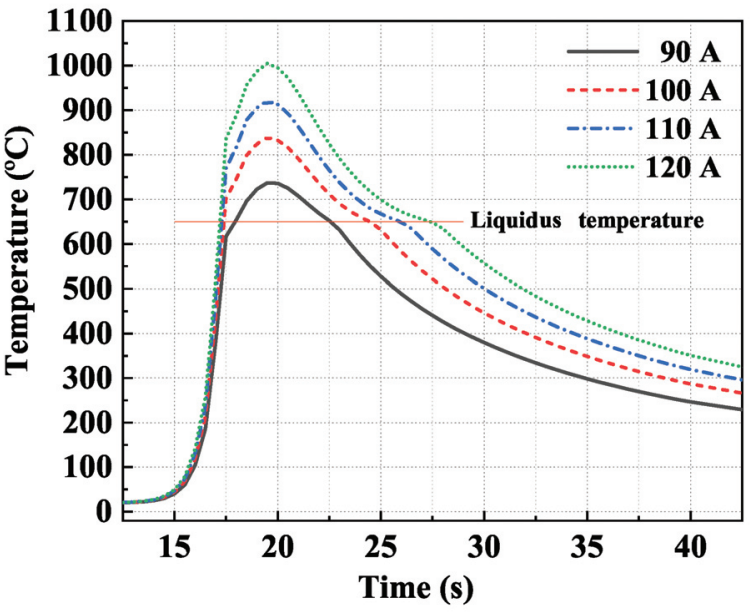

Fig. 14 - Thermal cycles at the interfaces (point 4 in Fig. 13) under different welding currents.

associated with the partition might reduce the supply of Fe, $\mathrm{Cr}$, and $\mathrm{Ni}$ to the IMC, and enable the dissolution to overcome the growth. This effect is not present in low-alloy steel substrates, and might possibly explain the differences observed in IMC behavior with stainless steel.

The limitations described restrict the applicability of the model to the case observed, making it only useful to enhance intuition about the balance of growth and dissolution. A more comprehensive model for prediction purposes is the focus of current work.

There exist three interfaces (marked as I1-I3) and five possible reactions (marked as R1-R5) illustrated in Fig. 16.

1) Increase in the thickness of the $\mathrm{Fe}_{2} \mathrm{Al}_{5}$ layer as a result of the diffusion of component $\mathrm{Al}$ across the bulk of the $\mathrm{Fe}_{2} \mathrm{Al}_{5}$ layer to interface $1\left(\mathrm{Fe}-\mathrm{Fe}_{2} \mathrm{Al}_{5}\right)$ and subsequent occurrence of the partial chemical reaction.

$$
\text { Interface 1: } 5 \mathrm{Al}_{\text {dif }}+2 \mathrm{Fe}_{\text {surf }}=\mathrm{Fe}_{2} \mathrm{Al}_{5}
$$

2) Increase in the thickness of the $\mathrm{Fe}_{2} \mathrm{Al}_{5}$ (decrease in the 

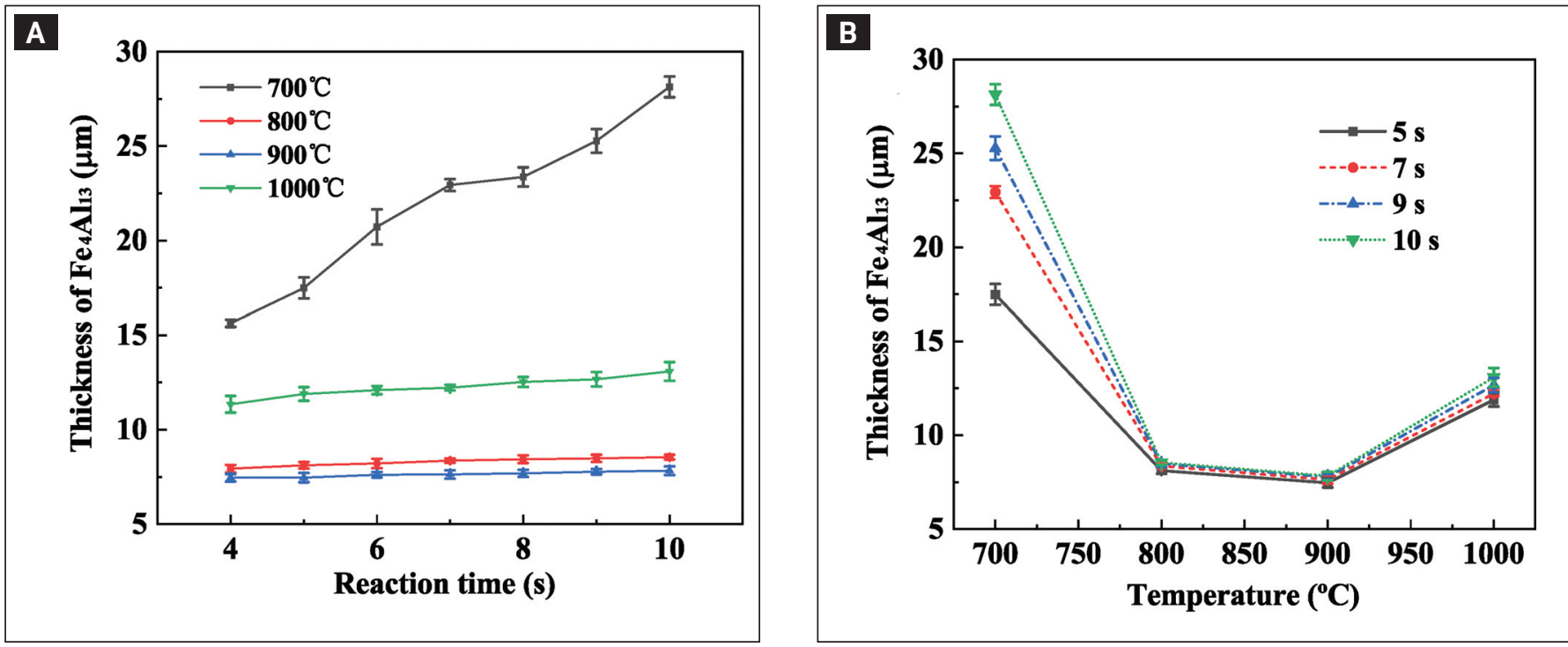

Fig. 15 - Relationship between hot-dipping parameters and thickness of $\mathrm{Fe}_{4} \mathrm{Al}_{13}: \mathrm{A}-$ Dipping time; $\mathrm{B}$ - dipping temperature.

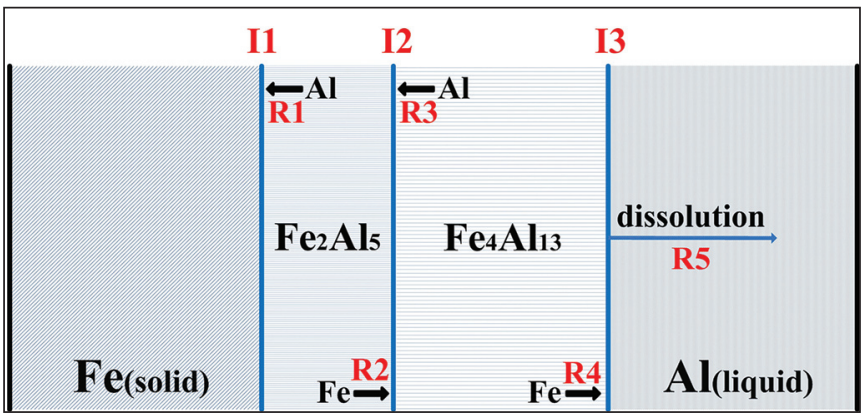

Fig. 16 - Schematic diagram for illustrating the reaction of interfaces.

thickness of the $\mathrm{Fe}_{4} \mathrm{Al}_{13}$ layer) as a result of the diffusion of the component $\mathrm{Fe}$ across the bulk of the $\mathrm{Fe}_{2} \mathrm{Al}_{5}$ layer to interface $2\left(\mathrm{Fe}_{2} \mathrm{Al}_{5}-\mathrm{Fe}_{4} \mathrm{Al}_{13}\right)$ and subsequent occurrence of partial chemical reaction.

$$
\text { Interface 2: } 6 \mathrm{Fe}_{\text {dif }}+5 \mathrm{Fe}_{4} \mathrm{Al}_{13}=13 \mathrm{Fe}_{2} \mathrm{Al}_{5}
$$

3) Increase in the thickness of the $\mathrm{Fe}_{4} \mathrm{Al}_{13}$ layer (decrease in the thickness of the $\mathrm{Fe}_{2} \mathrm{Al}_{5}$ layer) as a result of the diffusion of the component $\mathrm{Al}$ across the bulk of the $\mathrm{Fe}_{4} \mathrm{Al}_{13}$ layer to interface $2\left(\mathrm{Fe}_{2} \mathrm{Al}_{5}-\mathrm{Fe}_{4} \mathrm{Al}_{13}\right)$ and subsequent occurrence of the partial chemical reaction.

$$
\text { Interface 2: } 3 \mathrm{Al}_{\text {dif }}+2 \mathrm{Fe}_{2} \mathrm{Al}_{5}=\mathrm{Fe}_{4} \mathrm{Al}_{13}
$$

4) Increase in the thickness of the $\mathrm{Fe}_{4} \mathrm{Al}_{13}$ layer as a result of the diffusion of the component Fe across the bulk of the $\mathrm{Fe}_{4} \mathrm{Al}_{13}$ layer to interface $3\left(\mathrm{Fe}_{4} \mathrm{Al}_{13}-\mathrm{Al}\right)$ and subsequent occurrence of the partial chemical reaction.

$$
\text { Interface 2: } 4 \mathrm{Fe}_{\text {dif }}+13 \mathrm{Al}_{\text {surf }}=\mathrm{Fe}_{4} \mathrm{Al}_{13}
$$

5) Decrease in the thickness of the $\mathrm{Fe}_{4} \mathrm{Al}_{13}$ layer at interface $3\left(\mathrm{Fe}_{4} \mathrm{Al}_{13}-\mathrm{Al}\right)$ due to its dissolution in the liquid $\mathrm{Al}$ undersaturated with component Fe.

$$
\text { Interface 3: } \mathrm{Fe}_{4} \mathrm{Al}_{13}=4 \mathrm{Fe}+13 \mathrm{Al}
$$

Depending on the sign of the difference of the growth and dissolution (decomposition) rates, the layer is formed (at a positive value of this difference) or is dissolved (at a negative value) between interacting substances. A possible dominant mechanism in action is that interfacial kinetics and thermodynamics play a role in the dissolution and decomposition of the thick layer of $\theta-\mathrm{Fe}_{4} \mathrm{Al}_{13}$ into $\mathrm{FeAl}_{6}$ and $\mathrm{Fe}_{2} \mathrm{Al}_{9}$ phase.

Another interesting aspect to explore is the role of alloying elements in the melt and their effect on reaction kinetics. In this work, pure aluminum filler (ER1100) was used, and the IMC decreased in thickness with heat input, while the phases $\mathrm{FeAl}_{6}$ and $\mathrm{Fe}_{2} \mathrm{Al}_{9}$ were observed in the weld joint. In contrast, previous work (Ref. 68) used $\mathrm{Cu}$-containing welding wire (ER2319) and did not observe dissolution. In this case, the intermetallics in the melt were $\mathrm{Al}_{2} \mathrm{Cu}$ and no Fe-containing intermetallics were observed.

\section{Conclusions}

The relationship between heat input, microstructures, and mechanical behavior were studied in the GTA weld brazing process of aluminum alloy to stainless steel, and the mechanisms involved were further explored with hot-dip experiments.

TEM analysis of the steel/aluminum weld brazing interface showed two intermetallic layers: $\mathrm{Fe}_{2} \mathrm{Al}_{5}$ next to the steel, and $\mathrm{Fe}_{4} \mathrm{Al}_{13}$ on top of it. The bulk of the weld showed a structure of primary aluminum surrounded by eutecticcontaining $\mathrm{FeAl}_{6}$ and $\mathrm{Fe}_{2} \mathrm{Al}_{9}$.

In both weld brazing and hot-dipping experiments, the $\mathrm{Fe}_{4} \mathrm{Al}_{13}$ layer was the thickest by a factor of 4 or more, and essentially determined the thickness of the intermetallic layer. This is a novel observation, and it is in contrast with aluminum to carbon steel dissimilar joints where the $\mathrm{Fe}_{2} \mathrm{Al}_{5}$ layer dominates, but it is consistent with previous hot-dip- 
ping experiments. This observation also explains previous weld brazing experiments of aluminum to stainless steel in which the $\mathrm{Fe}_{2} \mathrm{Al}_{5}$ was so thin it was not observed.

The overall thickness of the intermetallic layers (essentially, the thickness of $\mathrm{Fe}_{4} \mathrm{Al}_{13}$ ) in the weld brazing experiments decreased with current at low and intermediate values (86.5 to $110 \mathrm{~A}$ ) and increased steeply at higher currents (100 to 120 A). This behavior had never been reported before in any type of weld brazing of ferrous alloys to aluminum.

Conduction-based heat transfer was used as a coarse approximation of temperatures at the $\mathrm{Fe} / \mathrm{Al}$ interface during weld brazing, and the results indicated as current increases, the melt temperature and solidification time also increased.

The hot-dipping experiments were performed at different temperatures consistent with the modeling estimates $\left(700^{\circ}\right.$ to $\left.1000^{\circ} \mathrm{C}\right)$ and showed an evolution of overall intermetallic thickness consistent with that observed in weld brazing. In these experiments, the thickness of the intermetallic layer decreases at low and intermediate temperatures $\left(700^{\circ}\right.$ to $\left.900^{\circ} \mathrm{C}\right)$ and increases at high temperatures $\left(900^{\circ}\right.$ to $\left.1000^{\circ} \mathrm{C}\right)$.

The strength of joints produced with weld brazing was tested and showed a trend closely related to the thickness of the intermetallic layer. At low and intermediate currents (86.5 to $100 \mathrm{~A}$ ), the strength of the joint increased (just as the thickness of the intermetallic decreased), and at high currents strength decreased rapidly, consistent with the increase in intermetallic layer. This observation is consistent with the common understanding that the thicker intermetallic layers are detrimental to joint strength. The peak strength measured was $238 \mathrm{MPa}$ for as-welded joints and $158 \mathrm{MPa}$ when reinforcement was eliminated.

The decreasing thickness of the intermetallic suggests the presence of a dissolution mechanism that has never been observed before in welding or brazing processes, and which deserves further study. Promoting the IMC dissolution or decomposition by adjusting welding procedures is a promising new way to control the IMC growth and improve the joint strength.

\section{Acknowledgments}

The authors appreciate the financial support from the National Natural Science Foundation of China (Grant No. 51605263), Key Technologies R\&D Program of Shandong Province (Grant No. 2017GGX30134), Climbing Research Innovation Team Program of Shandong Jiaotong University (Grant No. SDJTUC1802), and China Scholarship Council (CSC).

\section{References}

1. Martinsen, K., Hu, S., and Carlson, B. 2015. Joining of dissimilar materials. CIRP Annals 64(2): 679-699. DOI: 10.1016/ j.cirp.2015.05.006

2. Ashby, M. F. 2005. Materials selection in mechanical design. MRS Bulletin 30(12): 994-997. DOI: 10.1557/mrs2005.264

3. Tricarico, L., and Spina, R. 2010. Experimental investigation of laser beam welding of explosion-welded steel/aluminum structural transition joints. Materials \& Design 31(4): 1981-1992. DOI: 10.1016/j.matdes.2009.10.032

4. Martin, D. C. 1968. Method of brazing aluminum to stainless steel for high-stress-fatigue applications. NASA SP-5040.

5. Agudo, L., Eyidi, D., Schmaranzer, C. H., Arenholz, E., Jank, N., Bruckner, J., and Pyzalla, A. R. 2007. Intermetallic $\mathrm{Fe}_{x} \mathrm{Al}_{y}$-phases in a steel/Al-alloy fusion weld. Journal of Materials Science 42(12): 4205-4214. DOI: 10.1007/s10853-006-0644-0

6. Li, X., Scherf, A., Heilmaier, M., and Stein, F. 2016. The Alrich part of the Fe-Al phase diagram. Journal of Phase Equilibria and Diffusion 37(2): 162-173. DOI: 10.1007/s11669-015-0446-7

7. Grin, J., Burkhardt, U., and Ellner, M. 1994. Refinement of the $\mathrm{Fe}_{4} \mathrm{Al}_{13}$ structure and its relationship to the quasihomological homeotypical structures. Zeitschrift für Kristallographie 209(6): 479-487. DOI: 10.1524/zkri.1994.209.6.479

8. Van Alboom, A., Lemmens, B., Breitbach, B., De Grave, E., Cottenier, S., and Verbeken, K. 2017. Multi-method identification and characterization of the intermetallic surface layers of hot-dip Al-coated steel: $\mathrm{FeAl}_{3}$ or $\mathrm{Fe}_{4} \mathrm{Al}_{13}$ and $\mathrm{Fe}_{2} \mathrm{Al}_{5}$ or $\mathrm{Fe}_{2} \mathrm{Al}_{5+\mathrm{x}}$. Surface and Coatings Technology 324: 419-428. DOI: 10.1016/j.surfcoat. 2017.05.091

9. Kattner, U., and Burton, B. 1993. Al-Fe (aluminum-iron). Phase Diagrams of Binary Iron Alloys: 12-28.

10. Abe, Y., Mori, K., and Kato, T. 2012. Joining of high strength steel and aluminium alloy sheets by mechanical clinching with dies for control of metal flow. Journal of Materials Processing Technology 212(4): 884-889. DOI: 10.1016/j.jmatprotec. 2011.11.015

11. Abe, Y., Kato, T., and Mori, K. 2009. Self-piercing riveting of high tensile strength steel and aluminium alloy sheets using conventional rivet and die. Journal of Materials Processing Technology 209(8): 3914-3922. DOI: 10.1016/j.jmatprotec.2008.09.007

12. Naimon, E., Doyle, J., Rice, C., Vigil, D., and Walmsley, D. 1981. Diffusion welding of aluminum to stainless steel. Welding Journal 60(11): 17-20.

13. Kong, J. H., Okumiya, M., Tsunekawa, Y., Yun, K. Y., Kim, S. G., and Yoshida, M. 2014. A novel bonding method of pure aluminum and SUS304 stainless steel using barrel nitriding. Metallurgical and Materials Transactions A 45(10): 4443-4453. DOI: 10.1007/s11661-014-2380-4

14. Li, X., Ma, H., and Shen, Z. 2015. Research on explosive welding of aluminum alloy to steel with dovetail grooves. Materials \& Design 87: 815-824. DOI: 10.1016/j.matdes.2015.08.085

15. Yu, H., and Tong, Y. 2017. Magnetic pulse welding of aluminum to steel using uniform pressure electromagnetic actuator. The International Journal of Advanced Manufacturing Technology 91(5-8): 2257-2265. DOI: 10.1007/s00170-016-9928-y

16. Uday, M., Ahmad Fauzi, M., Zuhailawati, H., and Ismail, A. 2010. Advances in friction welding process: A review. Science and Technology of Welding and Joining 15(7): 534-558. DOI: 10.1179/136217110X12785889550064

17. Li, W., Vairis, A., Preuss, M., and Ma, T. 2016. Linear and rotary friction welding review. International Materials Reviews 61(2): 71-100. DOI: 10.1080/09506608.2015.1109214

18. Simar, A., and Avettand-Fenoel, M.-N. 2017. State of the art about dissimilar metal friction stir welding. Science and Technology of Welding and Joining 22(5): 389-403. DOI: 10.1080/13621718. 2016.1251712

19. DebRoy, T., and Bhadeshia, H., 2010. Friction stir welding of dissimilar alloys - A perspective. Science and Technology of Welding and Joining 15(4): 266-270. DOI: 10.1179/

$174329310 X 12726496072400$

20. Roulin, M., Luster, J., Karadeniz, G., and Mortensen, A. 1999. Strength and structure of furnace-brazed joints between aluminum and stainless steel. Welding Journal 78(5): 151-s to 155-s.

21. Bach, F. W., Beniyash, A., Lau, K., and Versemann, R. 2005. 
Joining of steel-aluminium hybrid structures with electron beam on atmosphere. Advanced Materials Research 6: 143-150. Trans Tech Publ. DOI: 10.4028/www.scientific.net/AMR.6-8.143

22. Wang, P., Chen, X., Pan, Q., Madigan, B., and Long, J. 2016. Laser welding dissimilar materials of aluminum to steel: An overview. The International Journal of Advanced Manufacturing Technology 87(9-12): 3081-3090. DOI: 10.1007/s00170-016-8725-y

23. Shi, Y., Zhang, G., Huang, Y., Lu, L., Huang, J., and Shao, Y. 2014. Pulsed double electrode GMAW brazing for joining of aluminum to steel. Welding Journal 93(6): 216-s to 224-s.

24. Ma, H., Qin, G., Bai, X., Wang, L., and Liang, Z. 2016. Effect of initial temperature on joint of aluminum alloy to galvanized steel welded by MIG arc brazing-fusion welding process. The International Journal of Advanced Manufacturing Technology 86(9-12): 3135-3143. DOI: 10.1007/s00170-016-8425-7

25. Bouche, K., Barbier, F., and Coulet, A. 1998. Intermetallic compound layer growth between solid iron and molten aluminium. Materials Science and Engineering A 249(1-2): 167-175. DOI: 10.1016/S0921-5093(98)00573-5

26. Bouayad, A., Gerometta, C., Belkebir, A., and Ambari, A. 2003. Kinetic interactions between solid iron and molten aluminium. Materials Science and Engineering A 363(1-2): 53-61. DOI: 10.1016/S0921-5093(03)00469-6

27. Chen, S., Yang, D., Zhang, M., Huang, J., and Zhao, X. 2016. Interaction between the growth and dissolution of intermetallic compounds in the interfacial reaction between solid iron and liquid aluminum. Metallurgical and Materials Transactions A 47(10): 5088-5100. DOI: 10.1007/s11661-016-3667-4

28. Shao, L., Shi, Y., Huang, J., and Wu, S. 2015. Effect of joining parameters on microstructure of dissimilar metal joints between aluminum and galvanized steel. Materials \& Design 66: 453-458. DOI: 10.1016/j.matdes.2014.06.026

29. Das, A., Shome, M., Das, C., Goecke, S.-F., and De, A. 2015. Joining of galvannealed steel and aluminium alloy using controlled short circuiting gas metal arc welding process. Science and Technology of Welding and Joining 20(5): 402-408. DOI: 10.1179/ $1362171815 Y .0000000032$

30. Mezrag, B., Deschaux-Beaume, F., and Benachour, M. 2015. Control of mass and heat transfer for steel/aluminium joining using cold metal transfer process. Science and Technology of Welding and Joining 20(3): 189-198. DOI: 10.1179/1362171814Y. 0000000271

31. Ünel, E., and Taban, E. 2017. Properties and optimization of dissimilar aluminum steel CMT welds. Welding in the World 61(1): 1-9. DOI: 10.1007/s40194-016-0386-9

32. Meco, S., Pardal, G., Ganguly, S., Williams, S., and McPherson, N. 2015. Application of laser in seam welding of dissimilar steel to aluminium joints for thick structural components. Optics and Lasers in Engineering 67: 22-30. DOI: 10.1016/j.optlaseng. 2014.10.006

33. Meco, S., Ganguly, S., Williams, S., and McPherson, N. 2014. Effect of laser processing parameters on the formation of intermetallic compounds in Fe-Al dissimilar welding. Journal of Materials Engineering and Performance 23(9): 3361-3370. DOI: 10.1007/ s11665-014-1106-5

34. Sun, J., Yan, Q., Gao, W., and Huang, J. 2015. Investigation of laser welding on butt joints of $\mathrm{Al} /$ steel dissimilar materials. $\mathrm{Ma}$ terials \& Design 83: 120-128. DOI: 10.1016/j.matdes.2015.05.069

35. Liu, J., Jiang, S., Shi, Y., Kuang, Y., Huang, G., and Zhang, H. 2015. Laser fusion-brazing of aluminum alloy to galvanized steel with pure Al filler powder. Optics \& Laser Technology 66: 1-8. DOI: 10.1016/j.optlastec.2014.08.004

36. Szczepaniak, A., Fan, J., Kostka, A., and Raabe, D. 2012. On the correlation between thermal cycle and formation of intermetallic phases at the interface of laser-welded aluminum-steel overlap joints. Advanced Engineering Materials 14(7): 464-472. DOI: 10.1002/adem.201200075
37. Reisgen, U., Otten, C., and Schoenberger, J. 2014. Investigations about the influence of the time-temperature curve on the formation of intermetallic phases during electron beam welding of steel-aluminium material combinations. Welding in the World 58(4): 443-454. DOI: 10.1007/s40194-014-0128-9

38. Gao, M., Chen, C., Mei, S., Wang, L., and Zeng, X. 2014. Parameter optimization and mechanism of laser-arc hybrid welding of dissimilar Al alloy and stainless steel. The International Journal of Advanced Manufacturing Technology 74(1-4): 199-208. DOI: 10.1007/s00170-014-5996-z

39. Dybkov, V. Reaction Diffusion and Solid State Chemical Kinetics: Handbook.

40. ASM International. 1990. Properties of wrought aluminum and aluminum alloys. ASM International Handbook Committee 2: 62-122.

41. Goldak, J., Chakravarti, A., and Bibby, M. 1984. A new finite element model for welding heat sources. Metallurgical Transactions B 15(2): 299-305. DOI: 10.1007/BF02667333

42. Chen, B.-Q., Hashemzadeh, M., and Soares, C. G. 2014. Numerical and experimental studies on temperature and distortion patterns in butt-welded plates. The International Journal of Advanced Manufacturing Technology 72(5-8): 1121-1131. DOI: 10.1007/s00170-014-5740-8

43. Burkhardt, U., Grin, Y., Ellner, M., and Peters, K. 1994. Structure refinement of the iron-aluminium phase with the approximate composition $\mathrm{Fe}_{2} \mathrm{Al}_{5}$. Acta Crystallographica Section $B$ 50(3): 313-316.

44. Black, P. 1955. The structure of $\mathrm{FeAl}_{3}$. I. Acta Crystallographica 8(1): 43-48.

45. Black, P. 1955. The structure of $\mathrm{FeAl}_{3}$. II. Acta Crystallographica 8(3): 175-182.

46. Ellner, M. 1995. Polymorphic phase transformation of $\mathrm{Fe}_{4} \mathrm{Al}_{13}$ causing multiple twinning with decagonal pseudosymmetry. Acta Crystallographica Section B 51(1): 31-36.

47. Walford, L. 1965. The structure of the intermetallic phase feal6. Acta Crystallographica 18(2): 287-291. DOI: 10.1107/ S0365110X65000610

48. Putyatin, A., Davydov, V., and Nesterenko, S. 1992. High temperature interactions in the $\mathrm{Fe}-\mathrm{Al}-\mathrm{C}$ system at 6 gpa pressure. Journal of Alloys and Compounds 179(1-2): 165-175. DOI:

10.1016/0925-8388(92)90216-V

49. Boström, M., Rosner, H., Prots, Y., Burkhardt, U., and Grin, Y. 2005. The $\mathrm{Co}_{2} \mathrm{Al}_{9}$ structure type revisited. Zeitschrift für anorganische und allgemeine Chemie 631(2-3): 534-541.

50. Dybkov, V. 1990. Interaction of $18 \mathrm{Cr}-10 \mathrm{Ni}$ stainless steel with liquid aluminium. Journal of Materials Science 25(8): 3615-3633.

51. Springer, H., Kostka, A., Dos Santos, J., and Raabe, D. 2011. Influence of intermetallic phases and Kirkendall-porosity on the mechanical properties of joints between steel and aluminium alloys. Materials Science and Engineering: A 528(13-14): 4630-4642.

52. Jácome, L. A., Weber, S., Leitner, A., Arenholz, E., Bruckner, J., Hackl, H., and Pyzalla, A. R. 2009. Influence of filler composition on the microstructure and mechanical properties of steelaluminum joints produced by metal arc joining. Advanced Engineering Materials 11(5): 350-358.

53. Geng, W., Wu, D., Sun, D., Li, H., and Che, Y. 2018. Microstructures and mechanical properties of plasma arc welded joints of ultra-high strength steel and aluminum alloy using $\mathrm{Al}-\mathrm{Si}$ and Al-Cu fillers. ISIJ International 58(6): 1108-1116.

54. He, H., Gou, W., Wang, S., Hou, Y., Ma, C., and Mendez, P. F. 2019. Kinetics of intermetallic compound layers during initial period of reaction between mild steel and molten aluminum. International Journal of Materials Research 110(3): 194-201. DOI:

10.3139/146.111735

55. He, H., Lin, S., Yang, C., Fan, C., and Chen, Z. 2013. Combination effects of Nocolok flux with Ni powder on properties and 
microstructures of aluminum-stainless steel TIG welding-brazing joint. Journal of Materials Engineering and Performance 22(11): 3315-3323.

56. Song, J., Lin, S., Yang, C.-L., Fan, C., and Ma, G. 2010. Analysis of intermetallic layer in dissimilar TIG welding-brazing butt joint of aluminium alloy to stainless steel. Science and Technology of Welding and Joining 15(3): 213-218.

57. Barmak, K., and Dybkov, V. 2004. Interaction of ironchromium alloys containing 10 and 25 mass\% chromium with liquid aluminium Part II formation of intermetallic compounds. Journal of Materials Science 39(13): 4219-4230.

58. Dybkov, V. 2000. Interaction of iron-nickel alloys with liquid aluminium Part II formation of intermetallics. Journal of Materials Science 35(7): 1729-1736.

59. Zhang, X., Li, X., and Chen, W. 2015. Interfacial reactions of duplex stainless steels with molten aluminum. Surface and Interface Analysis 47(6): 648-656.

60. Mondolfo, L. F. 2013. Aluminum Alloys: Structure and Properties. Elsevier.

61. Allen, C., O’Reilly, K., Cantor, B., and Evans, P. 1998. Intermetallic phase selection in 1 XXX Al alloys. Progress in Materials Science 43(2): 89-170. DOI: 10.1016/S0079-6425(98)00003-6

62. Griger, A., and Stefaniay, V. 1996. Equilibrium and nonequilibrium intermetallic phases in Al-Fe and Al-Fe-Si alloys. Journal of Materials Science 31(24): 6645-6652.

63. Yu, M., Shivpuri, R., and Rapp, R. 1995. Effects of molten aluminum on H13 dies and coatings. Journal of Materials Engineering and Performance 4(2): 175-181.

64. Zhao, J., Unuvar, C., Anselmi-Tamburini, U., and Munir, Z.
2007. Kinetics of current-enhanced dissolution of nickel in liquid aluminum. Acta Materialia 55(16): 5592-5600. DOI: 10.1016/ j.actamat.2007.06.016

65. Zhao, J., Unuvar, C., Anselmi-Tamburini, U., and Munir, Z. A. 2008. Microstructural evolution during the dissolution of nickel in liquid aluminum under the influence of an electric field. Acta Materialia 56(8): 1840-1848. DOI: 10.1016/j.actamat.2007.12.024

66. Zhao, J. 2008. Electric current effects on solid-solid and solidliquid metallic reactions. University of California, Davis.

67. Dutta, R., Majumdar, S., Laik, A., Singh, K., Kulkarni, U., Sharma, I., and Dey, G. 2011. Formation and characterization of aluminide coatings on alloy 800 substrate. Surface and Coatings Technology 205(19): 4720-4725. DOI: 10.1016/j.surfcoat. 2011.04.038

68. He, H., Wu, C., Lin, S., and Yang, C. 2019. Pulsed TIG welding-brazing of aluminum-stainless steel with an $\mathrm{Al}-\mathrm{Cu}$ twin hot wire. Journal of Materials Engineering and Performance 28(2): 1180-1189. DOI: 10.1007/s11665-018-3848-y
HUAN HE (welderhehuan@yahoo.com) and WENQIN GOU are with the Department of Mechanical Engineering, Shandong Jiaotong University, Jinan, China. HE and PATRICIO F. MENDEZ are with the Department of Chemical and Materials Engineer- ing, University of Alberta, Edmonton, Alberta, Canada. GOU, SANBAO LIN, and CHUNLI YANG are with the State Key Labora- tory of Advanced Welding and Joining, Harbin Institute of Technology, Harbin, China.

\section{Can We Talk?}

The Welding Journal staff encourages an exchange of ideas with you, our readers. If you'd like to ask a question, share an idea, or voice an opinion, you can call, write, email, or fax. Staff email addresses are listed below, along with a guide to help you interact with the right person.

\section{Publisher/Editor}

Mary Ruth Johnsen, mjohnsen@aws.org, ext. 238

General Management, Reprint Permission,

Copyright Issues, Editorial Content

\section{Sr. Editor}

Cindy Weihl, cweihl@aws.org, ext.256

Section News, SPRAYTIME®

\section{Features Editor}

Kristin Campbell, kcampbell@aws.org, ext. 257

Feature Articles, Industry News

\section{Associate Editor}

Katie Pacheco, kpacheco@aws.org, ext.275

Society News, New Products

\section{Education Editor}

Roline Pascal, rpascal@aws.org, ext.303

International News, Personnel

\section{Production Manager}

Zaida Chavez, zaida@aws.org, ext.265

Design and Production

Editor of Inspection Trends/Editor of Welding Journal en Español/Manager of Electronic Media Carlos Guzman, cguzman@aws.org, ext. 348 Inspection Trends, Spanish-Language Content, Design and Production

\section{Advertising}

Jeff Rhodes jeff.rhodes@mci-group.com and Kim Daniele kim.daniele@mci-group.com

\section{Subscriptions}

Thomas Lira, tlira@aws.org, ext. 351

Subscriptions Representative

Welding Journal Dept. 8669 NW 36 St., \#130 Miami, FL 33166 